\title{
Application of CFD to Rail Car and Locomotive Aerodynamics
}

\author{
James C. Paul ${ }^{1}$, Richard W. Johnson ${ }^{1}$, and Robert G. Yates ${ }^{2}$ \\ ${ }^{1}$ Airflow Sciences Corporation, 12190 Hubbard Street, Livonia, MI 48150, USA, \\ jpaul@airflowsciences.com \\ ${ }^{2}$ The Greenbrier Companies, 149 Saddle Oaks Court, Walnut Creek, CA 94596, USA, \\ bob.yates@gbrx.com
}

\begin{abstract}
CFD methods have been employed to solve a number of efficiency, safety and operational problems related to the aerodynamics of rail cars and locomotives. This paper reviews three case studies: 1) numerical models were employed to quantify the drag characteristics of two external railcar features; namely, well car side-posts and inter-platform gaps. The effects of various design modifications on train resistance and fuel usage were evaluated. 2) An operational safety issue facing railroad operators is wind-induced tip-over. A study was completed using CFD and wind tunnel tests to develop a database of tip-over tendencies for a variety of car types within the Norfolk Southern fleet. The use of this database in the development of a speed restricting system for the Sandusky Bay Bridge is also discussed. 3) Another safety issue involves the behavior of diesel exhaust plumes in the vicinity of locomotive cabs. Numerical simulations were performed for a variety of locomotives operating under a number of ambient conditions (wind speed, wind direction). The concentration of diesel exhaust at the operator cab window was quantified. Where appropriate, the studies provide information on the correlation of the CFD results with previously collected wind tunnel and field data.
\end{abstract}

\section{Introduction}

Railcar aerodynamic studies are typically undertaken to improve safety and increase fuel efficiency. A number of approaches are available to assist the engineer in developing improved designs, including numerical simulation, laboratory (wind tunnel) methods, and field tests. 
Significant advances have been made in the development of 3-D CFD codes, including Reynolds-Averaged Navier-Stokes (RANS), Unsteady ReynoldsAveraged Navier-Stokes (URANS), Large Eddy Simulation (LES), Detached Eddy Simulation (DES), Direct Numerical Simulation (DNS), spectral methods, vortex methods, and Lattice-Boltzmann methods [1, 2]. All of these have been applied to the evaluation of heavy vehicle aerodynamics [3, 4]. For the three studies presented below, appropriate tools were sought to provide practical engineering solutions within commercial timeframes and budgets. Because of the many configurations to be modeled, computationally-intensive methods such as LES, DES, and DNS could not be accommodated. Two 3-D RANS finite-volume simulation codes were selected: 1) a proprietary code, VISCOUS [5, 6], and 2) a commercial code, FLUENT [7]. The Reynolds stress tensor was addressed using the $\kappa-\varepsilon$ equations $[8,9]$. Although this method does not model detailed turbulent structures, it does predict average surface pressures and force differences with sufficient accuracy for rail car design and tipping moment determination [10]. The CFD simulations were supplemented with both wind tunnel and field tests.

\section{Section I: Aerodynamic Drag Reduction}

Studies aimed at reducing the tractive resistance of railroad trains have been performed since the advent of iron rails during the late $18^{\text {th }}$ century [11]. Aerodynamic drag is a major contributor to locomotive power requirements, along with climbing resistance (gravity), frictional resistance (rolling, track, flange, bearing, suspension losses), and the force required for acceleration or deceleration. Measurements made using instrumented cars and coast-down methods indicate aerodynamic resistance can account for over $90 \%$ of the tractive effort at higher train speeds [12 through 19].

\section{Review of Past Work}

The earliest study of train aerodynamics reported in the literature involved small-scale wind tunnel tests performed during 1898 at Purdue University [20]. A significant amount of research on this topic was conducted during the 1920s and 1930s and is reviewed by Hoerner [21] and Tietjens [22]. Results of research on train resistance components are included in papers by Davis [23], Hay [24], Engdahl [25], and Paul [26]. Following the 1973-1974 OPEC oil embargo [27], many U.S. railroads and railroad equipment manufacturers initiated research programs to evaluate methods of reducing tractive resistance of freight trains [28 through 39]. A significant series of studies was supported by the Association of American Railroads during the 1980s [25, 40, 41, 42]. Airflow Sciences Corporation served as primary contractor for this program and has continued to conduct engineering analysis and design studies for a variety of railroads and rail car manufacturers [43 
through 48]. Recent increases in fuel prices have once again generated interest in reducing train resistance.

\section{Approach}

During the current study, the aerodynamic performance of two types of welltype intermodal cars, each capable of transporting containers of varying lengths, were evaluated. Various design modifications aimed at reducing aerodynamic drag were modeled using RANS methods. Photos of the two well cars are shown in Figures 1 and 2.
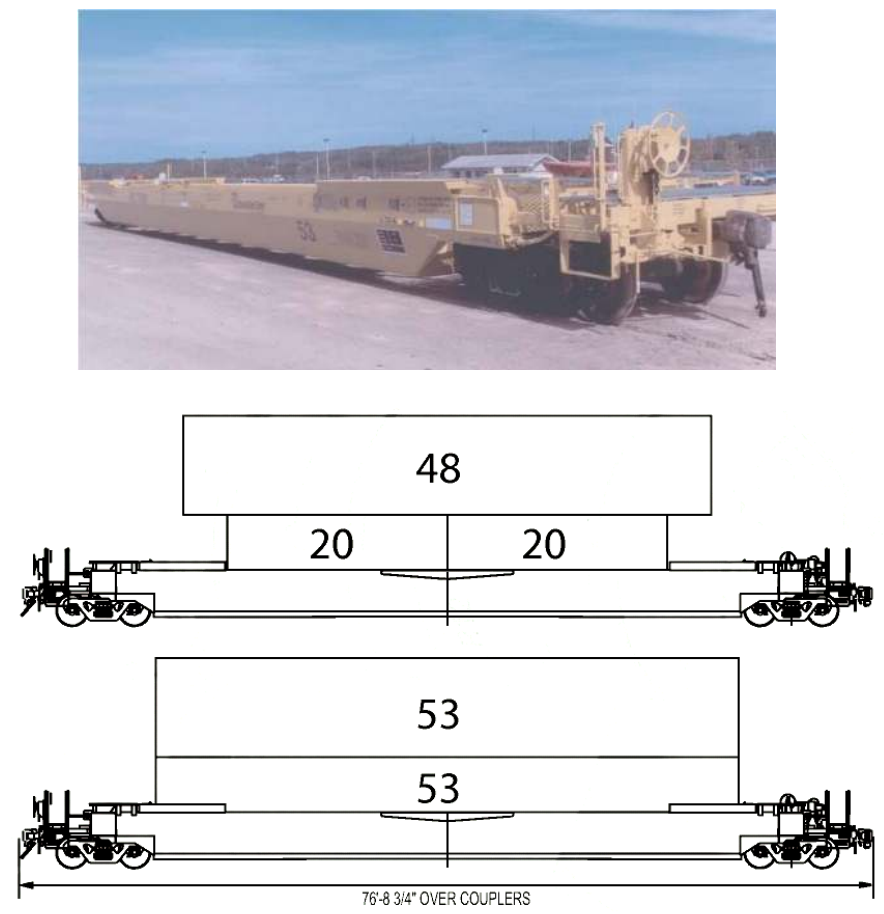

Fig. 1. Husky Stack Well-Type Intermodal Car. Schematic showing loading configuration with containers having lengths of 20', 48', and 53'

Two design features were modified to determine their effect on aerodynamic drag: 1) smooth sides versus exposed side posts, and 2) spacing between containers on adjacent cars. CFD models were coupled with an updated version of the AAR AERO program [42] to determine the drag area (see Equation 1) for various container loads and car position-in-train. A fuel consumption calculation was per- 
formed to determine the influence of reduced drag on locomotive fuel consumption.

$$
\mathrm{S}_{\mathrm{d}}=\text { Drag Area }=\mathrm{C}_{\mathrm{d}} \mathrm{A}
$$

$\begin{aligned} \text { where } & \mathrm{C}_{\mathrm{d}} & =\text { drag coefficient of rail car at zero degrees yaw } \\ \text { and } & \mathrm{A} & =\text { reference area (projected frontal area of rail car) }\end{aligned}$
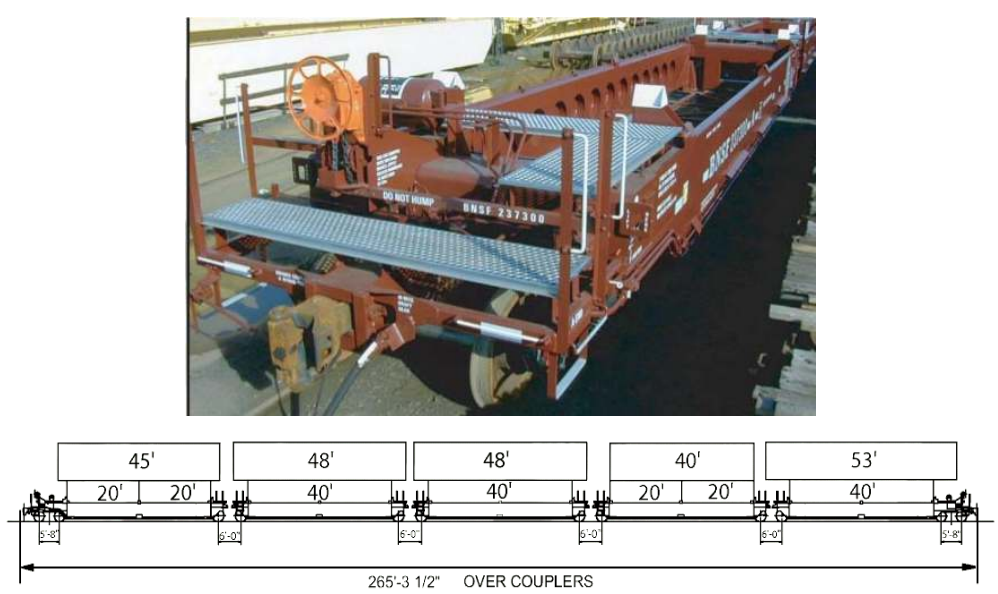

Fig. 2. Maxi-Stack Well-Type Intermodal Car. Schematic showing loading configuration with variety of container lengths.

Fuel consumption calculations are based on the equations developed by Paul, et. al. [26, pp. 8-9] [40, p.43]. Assuming the train is operating on straight, level track at constant speed, fuel consumption can be determined from a modified version of the Davis Equation [49]:

$$
\left[\begin{array}{c}
\text { Gallons of Fuel } \\
\text { Consumed per } \\
1,000 \text { miles }
\end{array}\right]=\mathrm{K}\left(0.0015 \mathrm{~W}+0.00256 \mathrm{~S}_{\mathrm{d}} \mathrm{V}^{2}+\mathrm{C} \mathrm{W}\right)
$$

where: $\mathrm{K}=$ Fuel consumed per distance traveled per unit of tractive resistance $=0.2038$ gallons $/ 1,000$ miles $/ \mathrm{lbf}$

$\mathrm{S}_{\mathrm{d}}=$ Consist Drag Area $\left(\mathrm{ft}^{2}\right)$

$\mathrm{V}=$ Train Speed (miles/hour)

$\mathrm{W}=$ Consist Weight (lbf)

$\mathrm{C}=$ Hill Factor $=0.0$ for level routes and 0.0007 for hilly routes

The first two terms on the right side of Equation 2 represent resistance due to rolling friction and aerodynamic drag, respectively. The last term accounts for the ef- 
fects of hill climbing. The constant, $\mathrm{K}$, relating fuel consumed per distance traveled per unit of tractive resistance is based on locomotive operational data obtained by members of the Association of American Railroads. Similarly, constant $\mathrm{C}$, the hill factor, is based on operational data for U.S. railroads.

Effects of Modifying Well Car Side Posts

Several researchers have evaluated the effects of modifying external structures on rail cars to reduce aerodynamic drag. Replacing exposed external ribs with smooth sides is particularly effective and offers the advantages of being low cost and easy to install. The table below provides a summary of several rib modification studies that were verified in the wind tunnel and during over-the-track test programs:

Table 1. Effects on Aerodynamic Drag of Rail Cars Due to Modification of Exposed External Ribs (Zero Degrees Yaw, Center Location in Train Consist)

\begin{tabular}{|c|c|c|c|c|}
\hline $\begin{array}{c}\text { Train Car } \\
\text { Type }\end{array}$ & $\begin{array}{c}\text { External } \\
\text { Surface } \\
\text { Configuration }\end{array}$ & Modification & $\begin{array}{c}\text { Drag } \\
\text { Reduction }\end{array}$ & Reference \\
\hline Passenger Car & $\begin{array}{c}\text { External Ribs and } \\
\text { Structure }\end{array}$ & Smooth Side & $6 \%$ & $\begin{array}{c}{[21] \text { pp. 12- }} \\
10 \text { to 12-11 }\end{array}$ \\
\hline ISO Container & External Ribs & Smooth Side & $10 \%$ & $\begin{array}{c}{[4]} \\
\text { pp. 434-435 }\end{array}$ \\
\hline Hopper Car & External Ribs & Smooth Side & $20 \%$ & $\begin{array}{c}{[37]} \\
\text { pp. 230-231 }\end{array}$ \\
\hline $\begin{array}{c}\text { Gondola Car } \\
\text { Well Type In- } \\
\text { termodal }\end{array}$ & $\begin{array}{c}\text { External Ribs } \\
\text { Trailers }\end{array}$ & Smooth Side & $13 \%$ & $\begin{array}{c}{[37]} \\
\text { pp. 230-231 }\end{array}$ \\
\hline $\begin{array}{c}\text { Skeleton Type } \\
\text { Intermodal }\end{array}$ & Platform Support & Shielded Ribs & $15 \%$ & $\begin{array}{c}{[36]} \\
\text { p. 214 }\end{array}$ \\
\hline Gondola Car & External Ribs & Smooth Side & $15 \%$ & {$[36]$} \\
\hline Gondola Car & External Ribs & Shielded Ribcaps & $17 \%$ & {$[39]$ p. 101 186} \\
\hline $\begin{array}{c}\text { Open Top } \\
\text { Hopper Car }\end{array}$ & External Ribs & Smooth Side & $30 \%$ & {$[41]$} \\
\hline
\end{tabular}

The external ribs comprising the structure of rail cars, containers, and trailers are typically of a size that extends beyond the boundary layer. Flow enters the inter-rib spaces along the vehicle side surfaces and creates a high pressure condition on the upstream side of each rib and a low pressure wake on the downstream side. Experiments have indicated this pressure distribution is essentially the same for each rib, except those located near the ends of the car, container, or trailer. 
The original design of the well-type intermodal cars evaluated during the current study included exposed external side ribs along the side of the well as shown in Figures 1 and 3. The high pressure on the upstream side and low pressure on the downstream side of each rib can be seen in the surface pressure plot of Figure 3. Details of the flow at a mid-height horizontal plane for one of the exposed ribs are plotted in Figure 4.

To reduce drag, a smooth, external surface was positioned at the outboard portion of the exposed side posts. This shielded the inter-rib cavities from the external flow as shown by the calculated pressure distribution in Figure 5. The change in drag area between the exposed ribs and smooth side versions of the well car was calculated based on the surface pressure changes obtained from the numerical model. This $\Delta \mathrm{C}_{\mathrm{d}} \mathrm{A}$ was referenced to the wind tunnel data using program AERO. The results are summarized in Table 2 for a single car loaded with various length containers. It is noted that drag reductions of $23 \%$ are obtained for the five-unit well car due to covering the exposed ribs with a smooth side. This result is similar to those presented in Table 1.

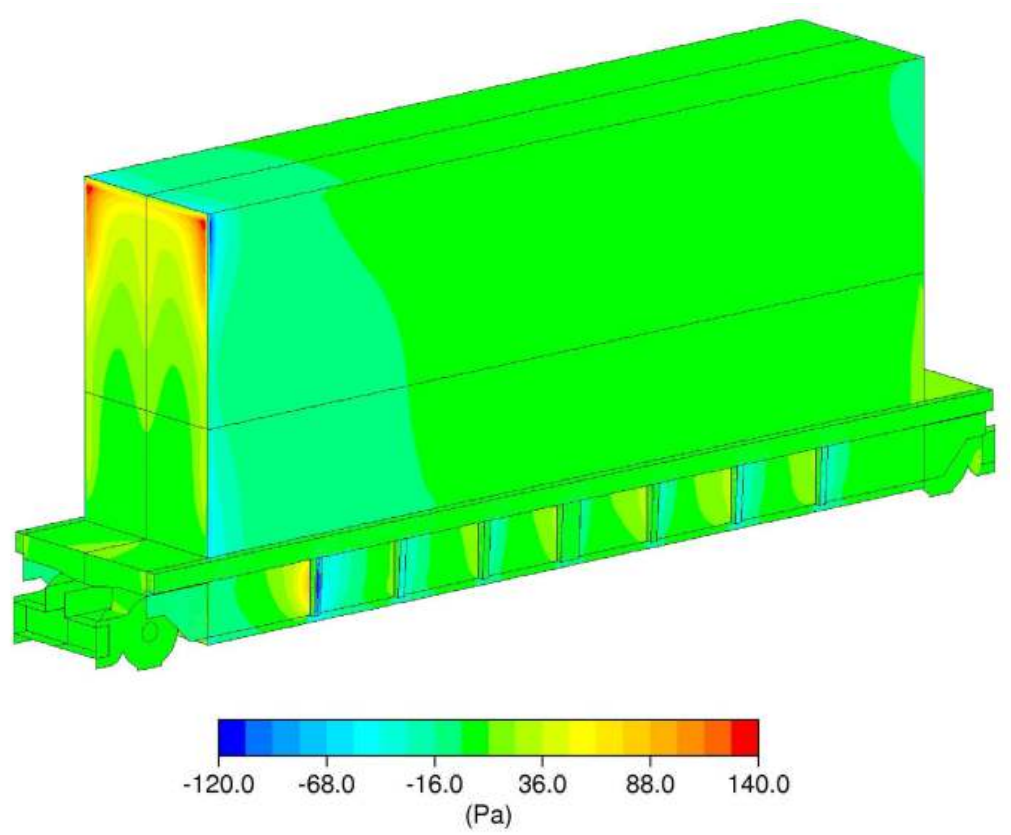

Fig. 3. Calculated Pressure Distribution on Well-Type Intermodal Car with Exposed Ribs (Side Posts), Train Direction is to the Left. 


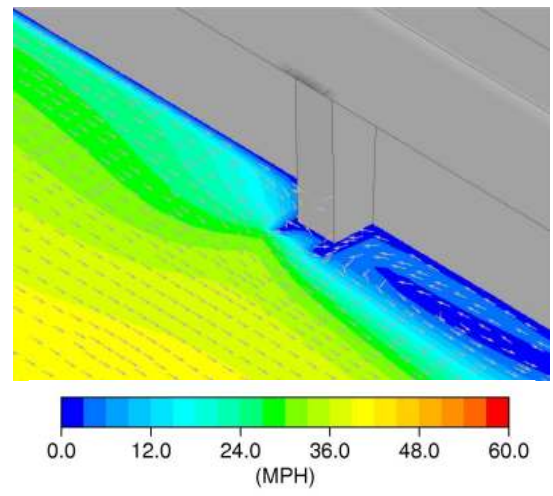

Fig. 4. Detail of Flow Near Well Car External Side Post at Mid-Height Horizontal Plane

Table 2. Drag Area Reduction for 5-Unit Well-Type Intermodal Car

\begin{tabular}{|l|c|c|}
\hline \multicolumn{1}{|c|}{$\begin{array}{c}\text { Load } \\
\text { Case }\end{array}$} & $\begin{array}{c}\text { Drag Area }\left(\mathrm{ft}^{2} \text { ) }\right. \\
\text { Smooth Sides }\end{array}$ & $\begin{array}{c}\text { Drag Area }\left(\mathrm{ft}^{2}\right) \\
\text { Exposed Side Posts }\end{array}$ \\
\hline $\begin{array}{l}\text { Two 40' long, 9.5' high containers } \\
\text { stacked in the well }\end{array}$ & 71.6 & 93.2 \\
\hline $\begin{array}{l}\text { One 40' long, 8.5' high container in } \\
\text { the well and one 40' long, 9.5' high } \\
\text { container on top }\end{array}$ & 70.6 & 92.3 \\
\hline $\begin{array}{l}\text { Two 20' long, 8.5' high containers in } \\
\text { the well and one 40' long, 8.5' high } \\
\text { container on top }\end{array}$ & 69.7 & 91.3 \\
\hline
\end{tabular}

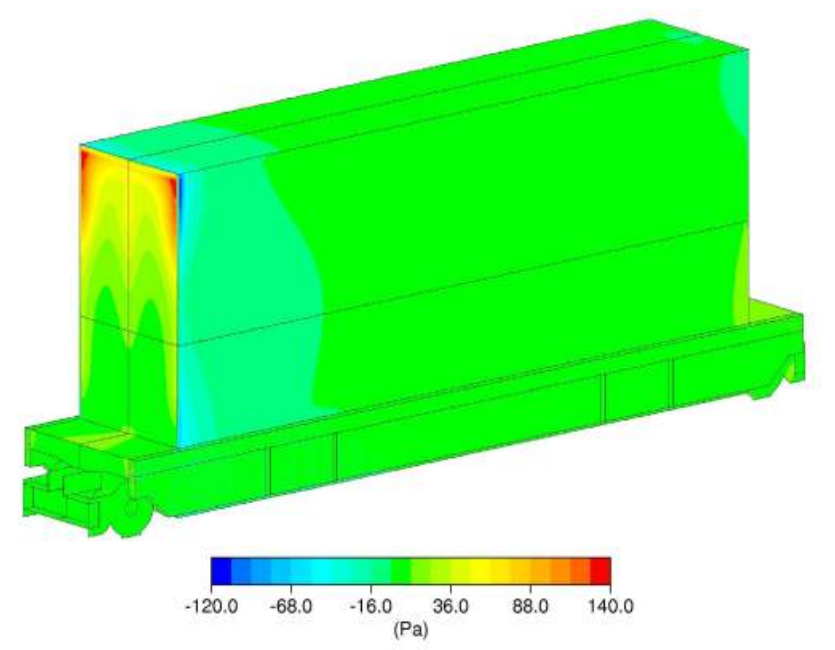

Fig. 5. Calculated Pressure Distribution on Well-Type Intermodal Car with Smooth Sides. Train Direction is to the Left. 


\section{Effects of Inter-Car Spacing}

Many researchers have evaluated the effects of position-in-train and inter-car spacing on aerodynamic drag [21, 40, 41]. For the case of small gaps between adjacent cars, the flow appears to move smoothly from the rear of the upstream car to the front of the downstream car. The flow in the gap region is a trapped vortex that does not interact substantially with the free-stream. Adjacent cars with narrow inter-car gaps thus act as a single body. As gap distances increase, the drag approaches that of multiple, single bodies [41 p. 99]. This observation has been applied to open top bulk materials cars, such as hopper and gondola cars, where vertical baffles have been employed to provide multiple trapped flow regions, thus preventing high speed air from impacting forward-facing surfaces [41, 50, 51]. For well-type intermodal cars, of course, the gap distance is determined by the container lengths on adjacent cars. The maximum allowable gap is defined by the design of the car ends and couplers. Car manufacturers have proposed placing smaller containers (e.g. 20' ISO containers) on support structures located above the couplers to reduce inter-car gaps. Figure 6 shows the calculated velocity field along the train longitudinal centerline for both a standard well car and a modified well car equipped with spine containers in the region above the couplers. The simulations indicated the drag area of the well car decreased from $44.1 \mathrm{ft}^{2}$ to 38.1 $\mathrm{ft}^{2}$ with the addition of the spine containers. However, the spine containers contributed $6.0 \mathrm{ft}^{2}$ of drag area, so no net gain was realized at zero degrees yaw [52].

The results of the various inter-car gap studies (both wind tunnel and CFD model results) were combined to produce the graph shown in Figure 7. The baseline inter-car gap for the subject well cars is 61.5 inches. The graph provides an indication of the magnitude of the drag changes as the gap distance is increased or decreased from the baseline value. It is interesting to note that the baseline gap places the adjacent containers well into the regime where they are exhibiting the behavior of multiple, sequential bodies. By decreasing the gap from 61.5 inches to 40 inches, the drag can be decreased by $25 \%$. 


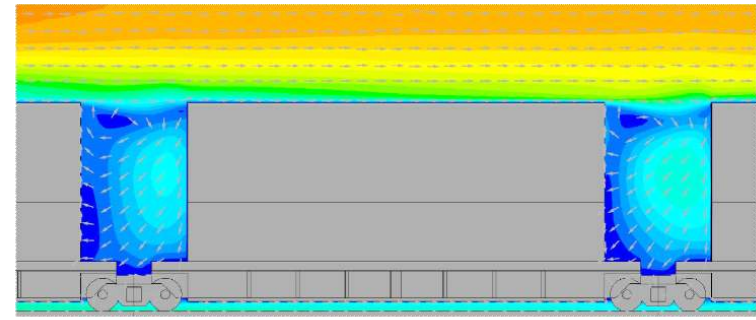

Standard Well Car

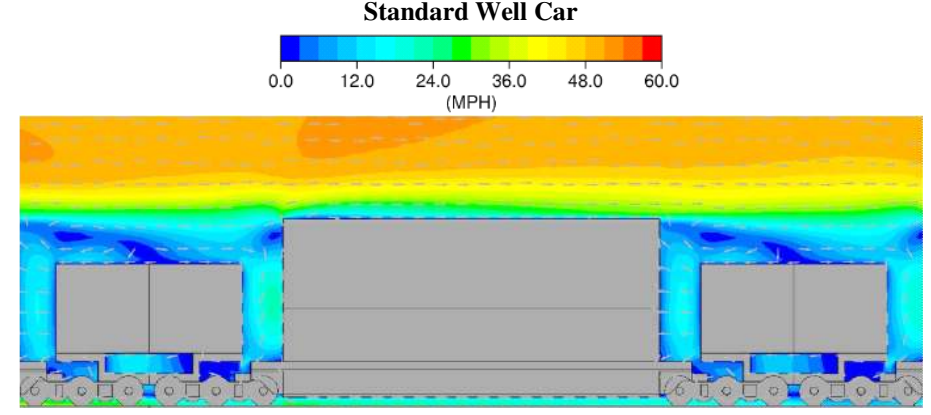

Well Car with Spline Containers

Fig. 6. Comparison of Centerline Flows for Standard and Spline-Type Well Cars

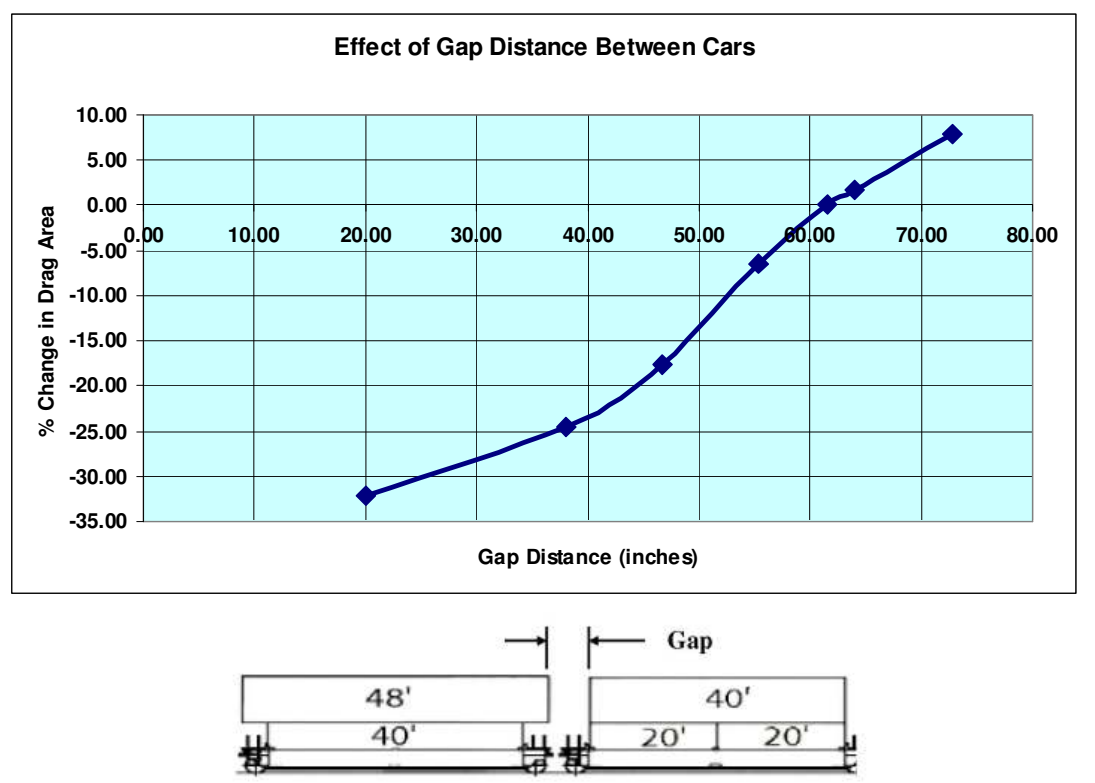

Fig. 7. Effect if Inter-Car Gap in Well Car Drag Area (Baseline Gap Distance is 61.5 Inches) 
Results and Conclusions: Section I: Aerodynamic Drag Reduction

The calculated drag reductions resulting from 1) covering the exposed well ribs with smooth sides and 2) reducing the gap distance between adjacent cars were utilized to produce the fuel savings projections shown in Tables 3 and 4 . For these comparisons, the following consist was assumed:

\section{Locomotives, Twenty 5-Unit Well Cars (= 200 48' Containers) Total Train Weight: 15,942,000 lbf}

Table 3. Fuel Consumption: Gallons per 1,000 Miles: Well Car Intermodal Train with Exposed Ribs and Smooth Sides.

\begin{tabular}{|l|c|c|c|c|c|c|}
\hline \multirow{2}{*}{ Configuration } & \multicolumn{3}{|c|}{ Level Route } & \multicolumn{3}{c|}{ Hilly Route } \\
\cline { 2 - 7 } & $\mathbf{4 0} \mathbf{~ M P H}$ & $\mathbf{5 0} \mathbf{~ M P H}$ & $\mathbf{6 0} \mathbf{~ M P H}$ & $\mathbf{4 0} \mathbf{~ M P H}$ & $\mathbf{5 0} \mathbf{~ M P H}$ & $\mathbf{6 0} \mathbf{M P H}$ \\
\hline Exposed Side Posts & 6,785 & 7,860 & 9,175 & 9,059 & 10,135 & 11,449 \\
\hline Smooth Sides & 6,287 & 7,082 & 8,053 & 8,561 & 9,356 & 10,328 \\
\hline
\end{tabular}

Table 4. Fuel Consumption: Gallons per 1,000 Miles: Well Car Intermodal Train with Various Inter-Car Gaps.

\begin{tabular}{|c|c|c|c|c|c|c|}
\hline \multirow{2}{*}{ Gap (inches) } & \multicolumn{3}{|c|}{ Level Route } & \multicolumn{3}{c|}{ Hilly Route } \\
\cline { 2 - 6 } & $\mathbf{4 0} \mathbf{~ M P H}$ & $\mathbf{5 0} \mathbf{~ P H}$ & $\mathbf{6 0} \mathbf{~ M P H}$ & $\mathbf{4 0} \mathbf{~ M P H}$ & $\mathbf{5 0} \mathbf{M P H}$ & $\mathbf{6 0} \mathbf{~ M P H}$ \\
\hline 61.5 & 6,785 & 7,860 & 9,175 & 9,059 & 10,135 & 11,449 \\
\hline 55 & 6,661 & 7,666 & 8,895 & 8,935 & 9,940 & 11,169 \\
\hline 47 & 6,450 & 7,337 & 8,421 & 8,725 & 9,612 & 10,696 \\
\hline 20 & 6,173 & 6,904 & 7,798 & 8,447 & 9,179 & 10,072 \\
\hline
\end{tabular}

Adding smooth sides to the well car improves fuel economy on level routes by $7.3 \%$ for low speeds up to $12 \%$ for high speeds. For hilly routes, fuel economy improvements vary from $5 \%$ at low speeds to $6 \%$ at high speeds. Reducing the inter-car gap also provides significant improvements in fuel economy. For level routes, reducing the inter-car gap from 61.5 inches to 47 inches reduces fuel usage by $5 \%$ at low speeds and $8 \%$ at high speeds. For hilly routes this reduction in gap distance improves fuel economy by $4 \%$ at low speeds and $7 \%$ at high speeds.

\section{Section II: Wind Induced Tip-Over}

Strong cross winds can lead to tip-over and derailment of train cars exhibiting large profiles and/or light weight, such as passenger coaches and intermodal equipment. The safety of railroad workers and the public is at risk during these events. The photo in Figure 8 shows a tip-over accident that occurred during 2006 on the Kahnawake Bridge (Montreal, Quebec, Canada). Several other recent wind-related accidents, including those listed below, have led to engineering studies aimed at preventing their occurrence. 
- 28 January 1987: Union Pacific Railroad: 4 empty containers blown from two TTX cars near Laramie, Wyoming; crosswind speeds measured to be 45 miles/hour.

- 24 March 1987: Union Pacific Railroad: 25 cars were derailed near Brule, Nebraska due to high winds, measured at 53 miles/hour.

- 11 November 1988: Consolidated Rail Corporation: 64 Road Railer intermodal cars derailed on the Sandusky Bay Causeway (Ohio) during high winds.

- 11 February 2003: Norfolk Southern Railway: train derailment on Sandusky Bay Causeway during high winds.

Cleanup costs can be significant and hence create an additional incentive for seeking an effective train speed restricting system aimed at reducing these events.

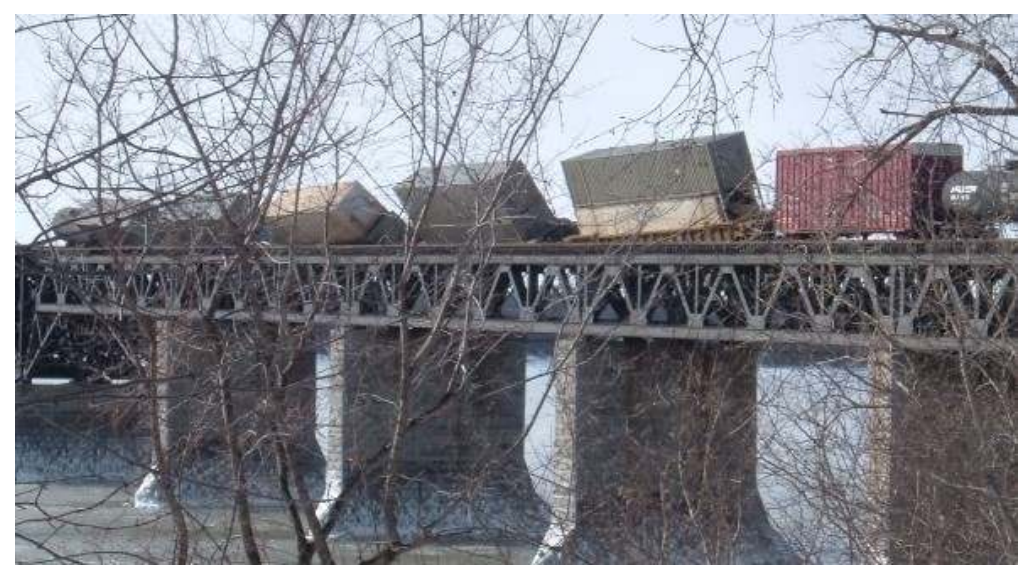

Photo Credit: http://www.citynoise.org, February 2006

Fig. 8. Freight Train Derailment: 18 February 2006, Montreal Quebec, Kahnawake Bridge, 67 mile/hour crosswinds.

Three primary goals were established for the current study:

- Develop railcar tipping moment (defined below) data base. This included gathering wind tunnel test data for high-population railcars and performing CFD simulations to gain additional insight into the aerodynamic conditions leading to tip-over events.

- Develop a real-time computer algorithm to signal appropriate train speed reductions during hazardous cross wind conditions.

- Select and locate wind sensors and configure and implement the train speed restricting system. 
Review of Past Work

The wind tunnel studies funded by the Association of American Railroads included force measurements of a wide variety of cars and locomotives at yaw angles up to $90^{\circ}$. Much of this work is summarized by Furlong, et. al. [41]. These studies provide a large database of car side forces and rolling moments under crosswind conditions.

Matschke, et. al. [53] performed a risk assessment of cross winds on high speed trains to define countermeasures for safe railway operation. Andersson, et. al. [54] identified locations in Sweden prone to high winds and possible train overturning and performed a risk assessment for safe train operation. Experimental methods for measuring side forces and rolling moments for high-speed trains were developed by Sanquer, et. al. [55]. Pressure measurements on double-stack freight cars during train passing conditions were made by MacNeill, et. al. [56] and used for comparison with CFD simulations. The simulations were employed to define conditions under which double-stack container cars are subject to tipover [57]. Hoppmann, et. al. [58] developed a wind prediction model as part of a railway safe operations system. Tipping effects on rail cars caused by jets emanating from tunnel pressure relief ducts were investigated by Polihonki, et. al. [59]. During 1988, Gielow, et. al. [60] conducted a series of wind tunnel tests using $16 \%$ scale models to determine the aerodynamic forces acting on a variety of rail cars, including intermodal and automobile transporters. The study culminated in development of a train-speed-restricting system to achieve safe operating conditions under high wind conditions along routes operated by Union Pacific Railroad. Additional evaluations on the tip-over behavior of autorack rail cars was performed by Airflow Sciences Corporation during 1998 [61]. Tipping moments were calculated as a function of train speed and cross wind speed and found to be less than half those of double-stack intermodal cars under the same cross wind conditions, primarily because of the higher pressures on the leeward side of the rounded-top autorack cars.

\section{Approach and Speed Restricting System Description}

The Sandusky Bay Causeway is located at the southwestern end of Lake Erie northwest of Sandusky, Ohio (see Figure 9). Trains moving across the causeway are subject to the high winds that occur frequently in this region. Norfolk Southern Railway funded an engineering effort to develop a train speed restricting system with the goal of eliminating tip-over accidents at this location. The project was divided into several phases and concluded during 2006 with the implementation of wind sensors located on the causeway, data acquisition hardware, and data analysis computers linked by the Norfolk Southern network [62]. 


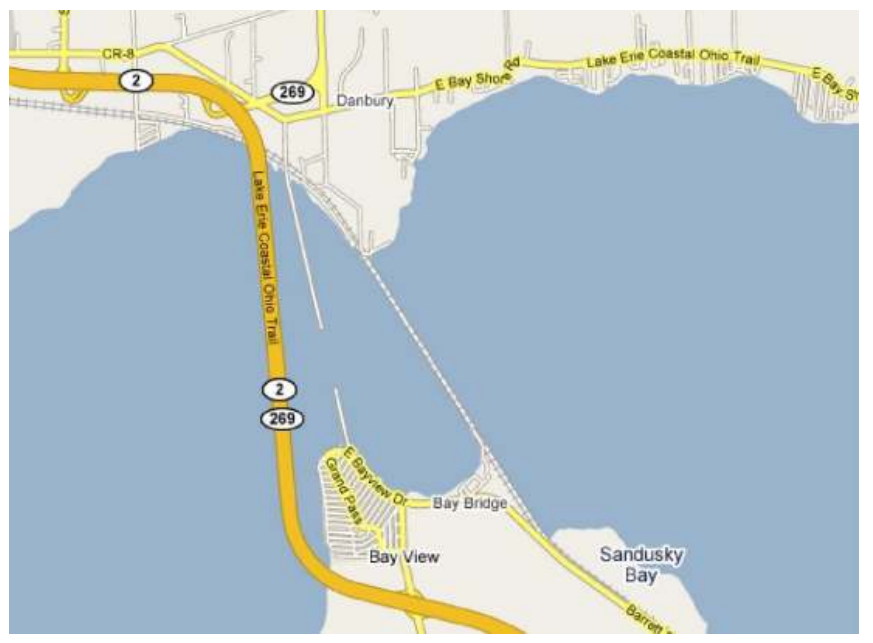

Fig. 9. Map Showing Sandusky Bay Causeway (Map Credit: Google Maps)

The main components of the Sandusky Bay Causeway Speed Restricting System are shown in the block diagram of Figure 10.

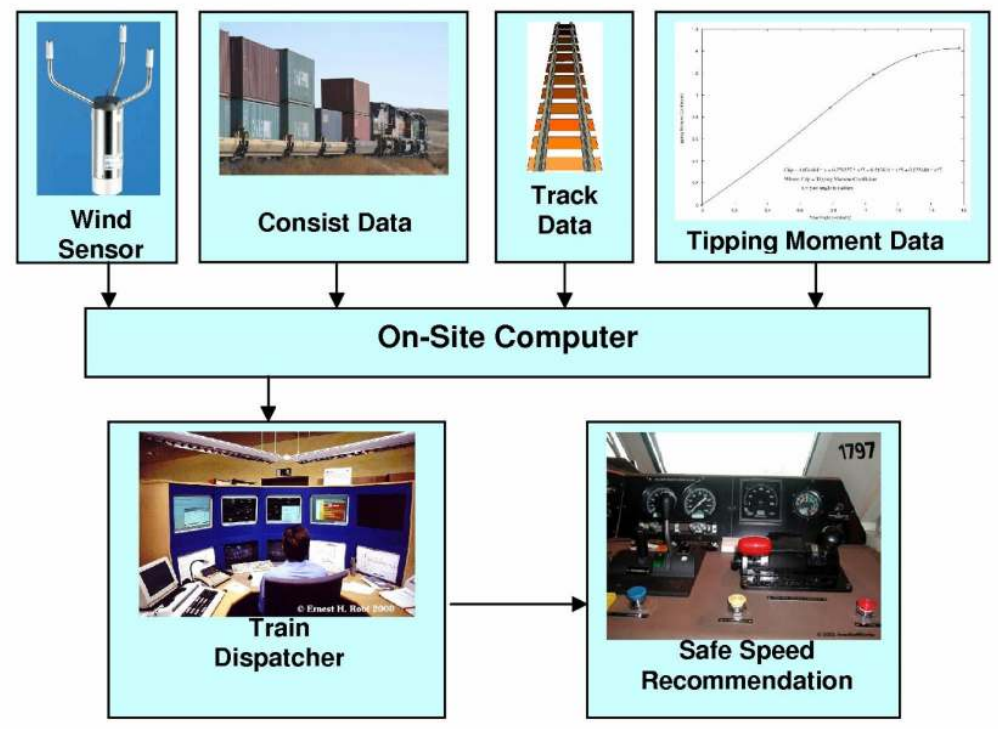

Fig. 10. Sandusky Bay Causeway Train Speed Restricting System Components 
Tipping moment data were obtained from wind tunnel tests and CFD simulations. Data for the following car types were obtained from earlier wind tunnel tests $[36,37,60,63]$. An example of the wind tunnel tipping moment coefficient plots is shown in Figure 11. CFD models were constructed for each of the cars represented in the wind tunnel tests. Comparisons between forces and moments obtained from the CFD models compared favorably with those obtained during the wind tunnel tests. As noted earlier, the FLUENT RANS models provide good correlation with the average pressures on the leeward side of the vehicle, leading to good agreement with the measured rolling moments. Peters [64, p. 464] showed similarly good agreement between calculated tipping moments (using FLUENT) and wind tunnel data. Additional CFD models were developed to obtain tipping moments for car types not included in the original wind tunnel tests. Car types were selected from lists, provided by Norfolk Southern Railway, of representative freight train consists that traverse the Sandusky Bay Causeway. Rail cars aerodynamic characteristics obtained from the CFD models are listed in Table 5 and those obtained from earlier wind tunnel tests are listed in Table 6. Velocity profiles and pressure distributions for typical CFD models, in this case a 53' welltype intermodal car at $90^{\circ}$ yaw, are shown in Figures 12 and 13, respectively.

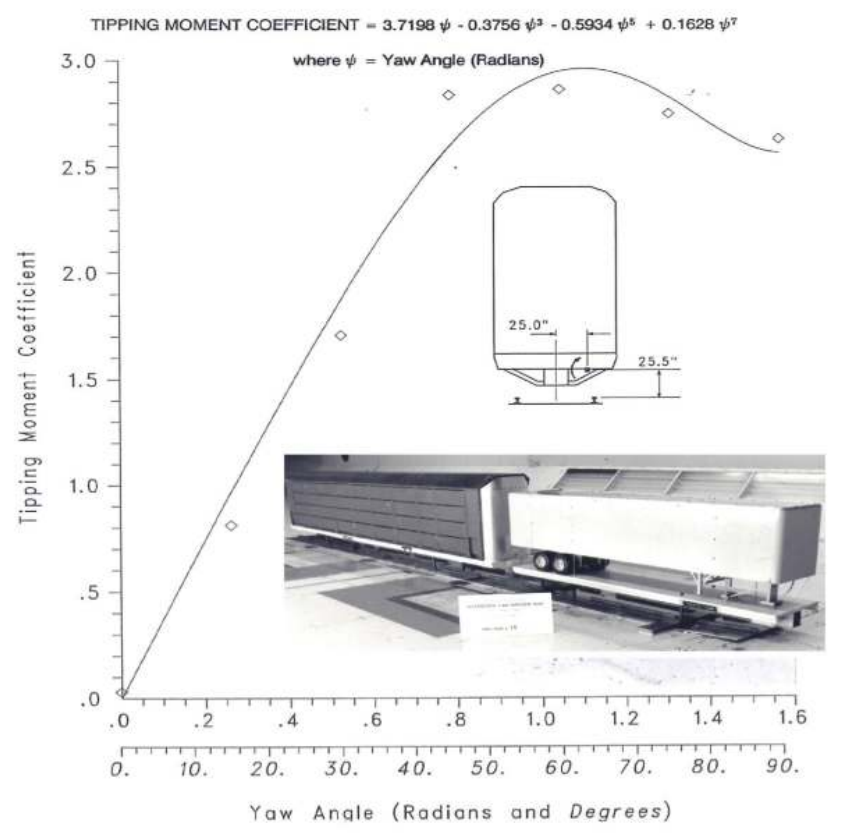

Fig. 11. Example Tipping Moment Plot Obtained from Wind Tunnel Test Data: Autorack Car. 
Table 5. Rail Cars Evaluated Using CFD Models $(\mathrm{C}=$ Container $)$

\begin{tabular}{|l|l|}
\hline \multicolumn{1}{|c|}{ Rail Car } & \multicolumn{1}{c|}{ Lading } \\
\hline BS177 Box Car & Empty \\
\hline BS216 Box Car & Empty \\
\hline BS89 Box Car & Empty \\
\hline RoadRailer (53' Trailer) & Empty \\
\hline HS46 Hopper Car & Empty \\
\hline H11D Hopper Car & Empty \\
\hline G86 Gondola Car & Empty \\
\hline 53' Well Car & 53' C on 53' C \\
\hline
\end{tabular}

Table 6. Rail Cars Evaluated Using Wind Tunnel Models $(\mathrm{C}=$ Container, $\mathrm{T}=$ Trailer $)$

\begin{tabular}{|l|l|}
\hline \multicolumn{1}{|c|}{ Rail Car } & \multicolumn{1}{c|}{ Lading } \\
\hline 48' Thrall Well Car & 40' C on 40' C \\
\hline 48' Thrall Well Car & 53' C on 48' C \\
\hline Gunderson Bulkhead Well Car & 40' C on 40' C \\
\hline Gunderson Bulkhead Well Car & 40' C on 40' C \\
\hline Gunderson Bulkhead Well Car & 48' C on 40' C \\
\hline Gunderson Bulkhead Well Car & 48' C on 40' C \\
\hline 89' Flat Car & Two 40' T \\
\hline 89' Flat Car & Two 45' T \\
\hline 89' Flat Car & One 40' C \\
\hline 89' Flat Car & Autorack \\
\hline
\end{tabular}

For each rail car, simulations were performed at yaw angles of $0^{\circ}, 45^{\circ}, 60^{\circ}, 75^{\circ}$, and $90^{\circ}$, with $0^{\circ}$ representing a pure headwind and $90^{\circ}$ a pure cross wind condition. Forces and moments were computed for the center cars only for both the wind tunnel and CFD models. The upstream and downstream cars were included to provide an accurate representation of the flow field [50, pp. 151-152]. 


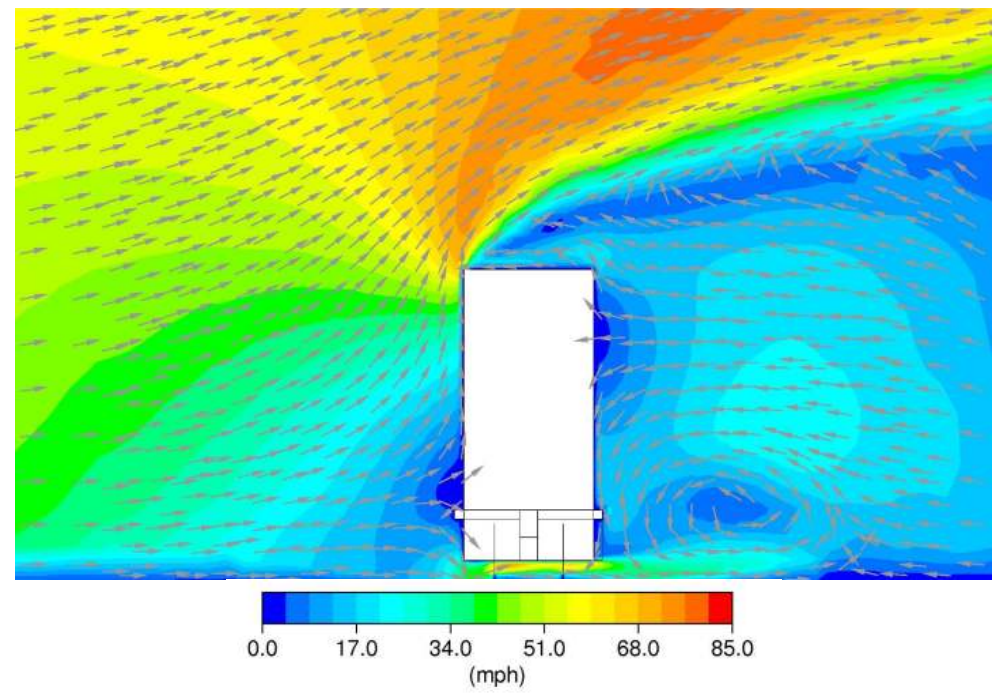

Fig. 12. Velocity Profile for $53^{\prime}$ Well-Type Intermodal Car at $90^{\circ}$ Yaw, Flow in Plane Perpendicular to Train Longitudinal Axis at Mid-Car Location.

Once the tipping moment relationships were established, $7^{\text {th }}$ order polynomial curve fits were developed (see Figure 11) and supplied as input to the train speed restricting algorithms.

A rail car will begin to rotate when the aerodynamic tipping moment exceeds the restoring moment. The restoring moment is taken as the weight of the railcar acting through the tipping arm. The aerodynamic tipping moment is taken as the weight of the rail car acting through the tipping arm, as illustrated in Figure 14. Note that dynamic effects are not included since they have been shown to be small compared to the wind forces and rail car weights. 


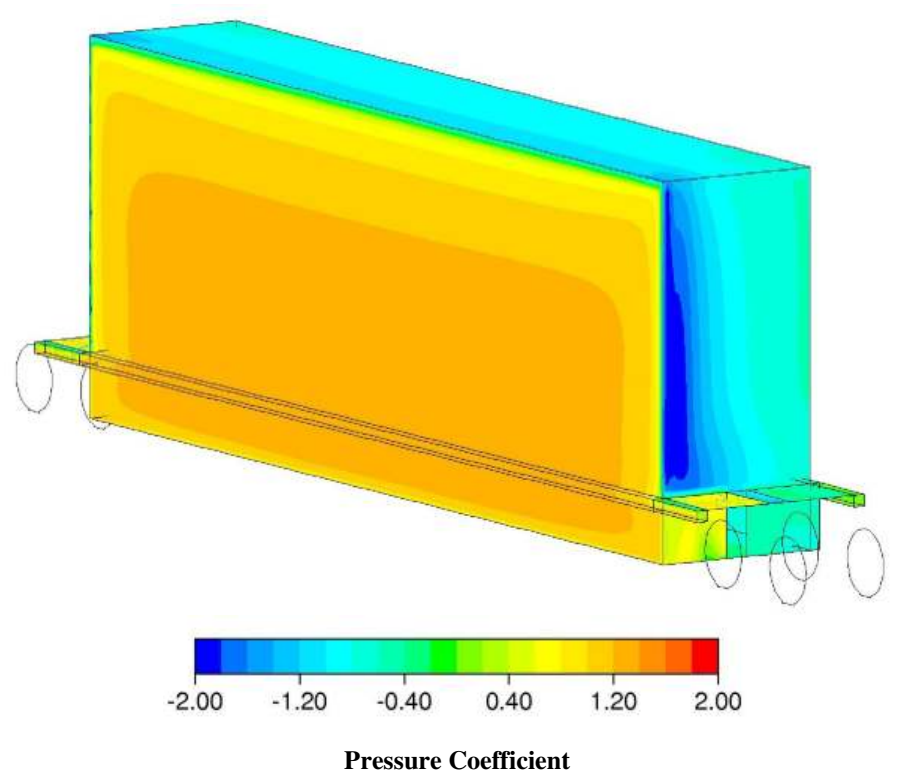

Fig. 13. Pressure Distribution, Windward Side, 53' Well-type Intermodal Car at $90^{\circ}$ Yaw

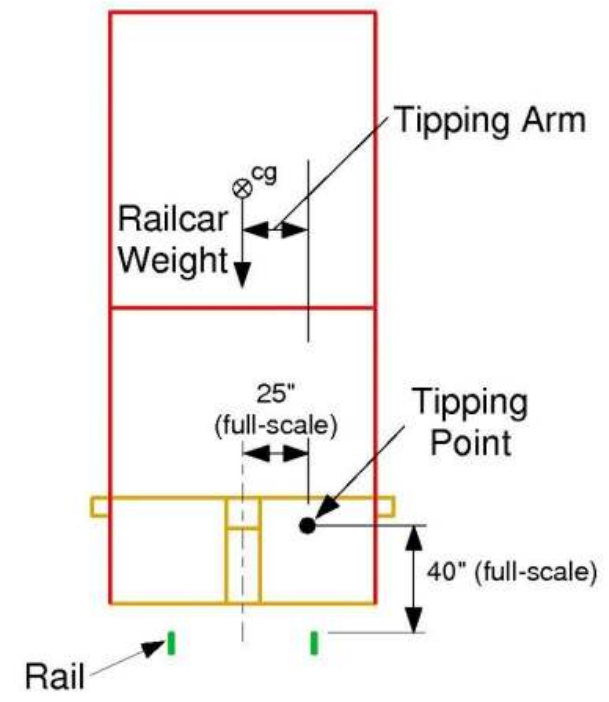

Fig. 14. Relationship Between Aerodynamic Tipping Moment and Restoring Moment 
At the onset of tipping:

$$
\begin{gathered}
\text { Restoring Moment }=\text { Aerodynamic Tipping Moment } \\
\mathrm{W} \cdot \mathrm{L}=1 / 2 \cdot \rho \cdot \mathrm{V}^{2} \cdot \mathrm{C}_{\text {tip }} \cdot \mathrm{A}_{\text {ref }} \mathrm{L}_{\text {ref }}
\end{gathered}
$$

where:

$$
\begin{aligned}
& \mathrm{W}=\text { Light Weight of Railcar (Less Trucks) Plus Empty Containers or Trailers } \\
& \mathrm{L}=\text { Tipping Arm (Horizontal Distance between Railcar cg and Tipping Point) } \\
& \rho \quad=\text { Air Density } \\
& \mathrm{V}=\text { Wind Velocity Relative to Train } \\
& \mathrm{C}_{\text {tip }}=\text { Tipping Moment Coefficient } \\
& \mathrm{A}_{\text {ref }}=\text { Reference Area }=100 \mathrm{ft}^{2} \\
& \mathrm{~L}_{\text {ref }}=\text { Reference Length }=50 \mathrm{ft}
\end{aligned}
$$

As noted above, $\mathrm{C}_{\text {tip }}$ is defined as a function of yaw angle $(\psi)$ using a $7^{\text {th }}$ order polynomial curve fit of the form:

$$
\mathrm{C}_{\text {tip }}=\mathrm{a} \cdot \psi+\mathrm{b} \cdot(\psi)^{3}+\mathrm{c} \cdot(\psi)^{5}+\mathrm{d} \cdot(\psi)^{7}
$$

The parameters a, b, c, d are the polynomial curve fit coefficients. Yaw angle and relative wind speed $(\mathrm{V})$ are both functions of train speed $\left(\mathrm{V}_{\mathrm{t}}\right)$, wind speed $\left(\mathrm{V}_{\mathrm{w}}\right)$, and wind angle $(\theta)$ relative to the track. The sketch below shows the relationship between these variables.

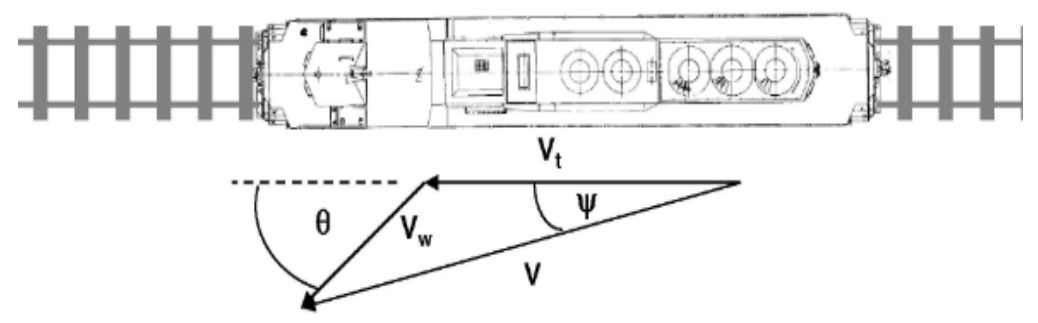

Thus, relative wind speed and yaw angle can be expressed as:

$$
\begin{aligned}
& \mathrm{V}^{2}=\left(\mathrm{V}_{\mathrm{t}}+\mathrm{V}_{\mathrm{w}} \cdot \cos (\theta)\right)^{2}+\left(\mathrm{V}_{\mathrm{w}} \cdot \sin (\theta)\right)^{2} \\
& \psi=\tan ^{-1}\left[\mathrm{~V}_{\mathrm{w}} \cdot \sin (\theta) /\left(\mathrm{V}_{\mathrm{t}}+\mathrm{V}_{\mathrm{w}} \cdot \cos (\theta)\right)\right]
\end{aligned}
$$

Recall that the equation for safe train speed comes from a balance of the aerodynamic tipping moment and the restoring moment: 


$$
0=\mathrm{W} \cdot \mathrm{L}-1 / 2 \cdot \rho \cdot \mathrm{V}^{2} \cdot \mathrm{C}_{\mathrm{tip}} \cdot \mathrm{A}_{\mathrm{ref}} \cdot \mathrm{L}_{\mathrm{ref}}
$$

Substituting the expressions for $\mathrm{V}$ and Ctip into the above equation yields the expression to be solved for safe train speed:

$$
0=\mathrm{W} \cdot \mathrm{L}-\mathrm{1} / 2 \cdot \rho \cdot\left[\left(\mathrm{V}_{\mathrm{t}}+\mathrm{V}_{\mathrm{w}} \cdot \cos (\theta)\right)^{2}+\left(\mathrm{V}_{\mathrm{w}} \cdot \sin (\theta)\right)^{2}\right] \cdot\left[\mathrm{a} \cdot \psi+\mathrm{b} \cdot(\psi)^{3}+\mathrm{c} \cdot(\psi)^{5}+\mathrm{d} \cdot(\psi)^{7}\right] \cdot \mathrm{A}_{\text {ref }} \cdot \mathrm{L}_{\text {ref }}
$$

Because $\psi$ is a function of $\mathrm{V}_{\mathrm{t}}$, numerical methods must be used to solve the above equation.

The weight used for each railcar is the light weight (less the truck weight) plus the empty weight of the appropriate container(s) or trailers. Unloaded weights are used in order to obtain the most conservative (lowest) tipping speeds for each railcar. The weight $(\mathrm{W})$, and tipping arm (L), and tipping point for each rail car were included in the train speed restricting system database.

Wind data were obtained using an ultrasound-based anemometer located at the Causeway. The sensor was located 500 feet north of the bridge on the lake side to avoid interference by the bridge structure. The sensor is programmed to provide wind speed and direction at 5 second intervals.

Three separate computer algorithms work together to form the core of the Sandusky Bay speed restricting system. The names of these algorithms are SRS (acronym for Speed Restricting System), Wind, and Safespeed. Each performs a specific task in the computation and display of safe train speeds. Program SRS is installed on the Train Dispatcher's computer. Programs Wind and Safespeed are installed on the computer located at the Causeway. Program Wind acquires data from the anemometer and provides the information to Program Safespeed which, in turn, calculates the tipping speed for each rail car in the consist. These files are transferred to SRS for display on the Dispatcher's console.

\section{Results and Conclusions, Section II: Wind-Induced Tip-Over}

Wind tunnel and CFD investigations of a variety of freight cars were used to assemble a tipping moment data base for cross wind conditions. Each of the rail cars included in the data base exhibits a particular type of tip-over behavior as summarized in Table 7. These data served as the basis for development of a realtime speed restricting system for the Sandusky Bay Causeway. The system includes a set of computer algorithms for calculating safe train speeds based on wind data obtained from a site-mounted anemometer. 
Table 7a. Rail Car Tipping Characteristics, Car Parameters

\begin{tabular}{|c|c|c|c|c|}
\hline \multirow[b]{2}{*}{ Railcar } & \multicolumn{2}{|c|}{$\begin{array}{l}\text { Tipping Point Relative to } \\
\text { Centerline Top-of-Rail Position }\end{array}$} & \multirow{2}{*}{$\begin{array}{l}\text { Railcar Light } \\
\text { Weight } \\
\text { Including } \\
\text { Trucks (Ibs) }\end{array}$} & \multirow{2}{*}{$\begin{array}{l}\text { Unloaded } \\
\text { Lading } \\
\text { Weight } \\
\text { (lbs) }\end{array}$} \\
\hline & $\begin{array}{c}\text { Horizontal } \\
\text { Location (in.) }\end{array}$ & $\begin{array}{c}\text { Vertical } \\
\text { Location (in) }\end{array}$ & & \\
\hline BS177 Box Car & 25 & 30 & 66,400 & 0 \\
\hline BS216 Box Car & 25 & 30 & 77,400 & 0 \\
\hline BS 89 Box Car & 25 & 30 & 111,800 & 0 \\
\hline 53 Foot RoadRailer & 28.25 & 0 & - & 15,800 \\
\hline HS46 Hopper Car & 25 & 30 & 80,000 & 0 \\
\hline H11D Hopper Car & 25 & 30 & 56,300 & 0 \\
\hline G86 Gondola Car & 25 & 30 & 59,000 & 0 \\
\hline 53 Foot Well Car & 25 & 40 & 50,000 & 20,000 \\
\hline 48 Foot Thrall Well Car & 25 & 40 & 48,900 & 14,800 \\
\hline 48 Foot Thrall Well Car & 25 & 40 & 48,900 & 19,000 \\
\hline Gunderson Bulkhead Well Car & 25 & 40 & 41,000 & 14,800 \\
\hline Gunderson Bulkhead Well Car & 50.3 & 125.5 & - & 7,400 \\
\hline Gunderson Bulkhead Well Car & 25 & 40 & 41,000 & 16,400 \\
\hline Gunderson Bulkhead Well Car & 53.3 & 125.5 & - & 9,000 \\
\hline 89 Foot Car & 25 & 25.5 & 68,000 & 26,000 \\
\hline 89 Foot Car & 25 & 25.5 & 68,000 & 28,000 \\
\hline 89 Foot Car & 48 & 47.5 & 68,000 & 7,400 \\
\hline 89 Foot Car & 25 & 25.5 & 97,000 & 0 \\
\hline
\end{tabular}

Table 7b. Rail Car Tipping Characteristics, Manner of Tipping

\begin{tabular}{|l|c|l|}
\hline \multicolumn{1}{|c|}{ Railcar } & $\begin{array}{c}\text { Total Weight } \\
\text { of Tipping } \\
\text { Railcar and } \\
\text { Lading (Ibs) }\end{array}$ & \multicolumn{1}{c|}{$\begin{array}{c}\text { Manner } \\
\text { of } \\
\text { Tipping }\end{array}$} \\
\hline BS177 Box Car & 42400 & Railcar tips off trucks \\
\hline BS216 Box Car & 53400 & Railcar tips off trucks \\
\hline BS 89 Box Car & 87800 & Railcar tips off trucks \\
\hline 53 Foot RoadRailer & 27400 & Combined trailer \& trucks tip off rail \\
\hline HS46 Hopper Car & 56000 & Railcar tips off trucks \\
\hline H11D Hopper Car & 32300 & Railcar tips off trucks \\
\hline G86 Gondola Car & 35000 & Railcar tips off trucks \\
\hline 53 Foot Well Car & 46000 & Combined trailer \& trucks tip off rail \\
\hline 48 Foot Thrall Well Car & 39700 & Combined trailer \& trucks tip off rail \\
\hline 48 Foot Thrall Well Car & 43900 & Combined trailer \& trucks tip off rail \\
\hline Gunderson Bulkhead Well Car & 43800 & Combined trailer \& trucks tip off rail \\
\hline Gunderson Bulkhead Well Car & 7400 & Top container tips off bottom container \\
\hline Gunderson Bulkhead Well Car & 45400 & Combined trailer \& trucks tip off rail \\
\hline Gunderson Bulkhead Well Car & 9000 & Top container tips off bottom container \\
\hline 89 Foot Car & 70000 & Combined trailer \& trucks tip off rail \\
\hline 89 Foot Car & 72000 & Combined trailer \& trucks tip off rail \\
\hline 89 Foot Car & 51400 & Container blows off Railcar \\
\hline 89 Foot Car & 73000 & Railcar tips off trucks \\
\hline
\end{tabular}




\section{Section III: Diesel Exhaust Plume Behavior}

Many studies have indicated a relation between occupational exposure to diesel exhaust and diseases of the lung [65-68]. The relative risk (RR) for lung cancer, for example, among those classified as having been exposed to diesel exhaust, is approximately 1.2 to 1.5 times the risk in those classified as unexposed. Diesel exhaust emissions contain hundreds of chemical compounds, which are partly in the gaseous phase and partly in the particulate phase. Railroad locomotive operators have issued complaints regarding diesel exhaust entering the cab through open windows [69]. Most diesel particles are small enough $(0.02$ to $0.5 \mu \mathrm{m})$ to be transported deep into the lungs, where they pose the greatest hazard to human health [70, 71]. The goal of the current study is to evaluate the behavior of exhaust plumes issuing from diesel locomotives and quantify the levels of exhaust components at the operator cab window.

\section{Review of Past Work}

It is well known that separation zones on the leeward sides of large rectangular objects can entrain exhaust flows. To prevent "sick building" syndrome, for example, the American Society of Heating, Refrigeration, and Air Conditioning Engineers publishes guidelines for exhaust stack heights and intake vent locations for buildings and industrial facilities [72]. During wind tunnel tests completed for General Electric Transportation Systems during 1986 [73], smoke flow visualization methods were employed to assess the behavior of the simulated diesel engine exhaust plume for a locomotive. The study showed the plume was relatively unaffected by passive changes to the locomotive surface (strakes, baffles, vanes). As the photo in Figure 15 shows, the exhaust is entrained within a strong vortex pattern on the leeward side of the locomotive that envelopes the operator's cab when the locomotive is operated with the long hood forward. It was shown that an auxiliary blower is effective at moving the plume above the operator's cab as shown in Figure 16. Operating the locomotives with the short hood forward significantly reduces the concentration of the plume on the lead locomotive operator's cab. 


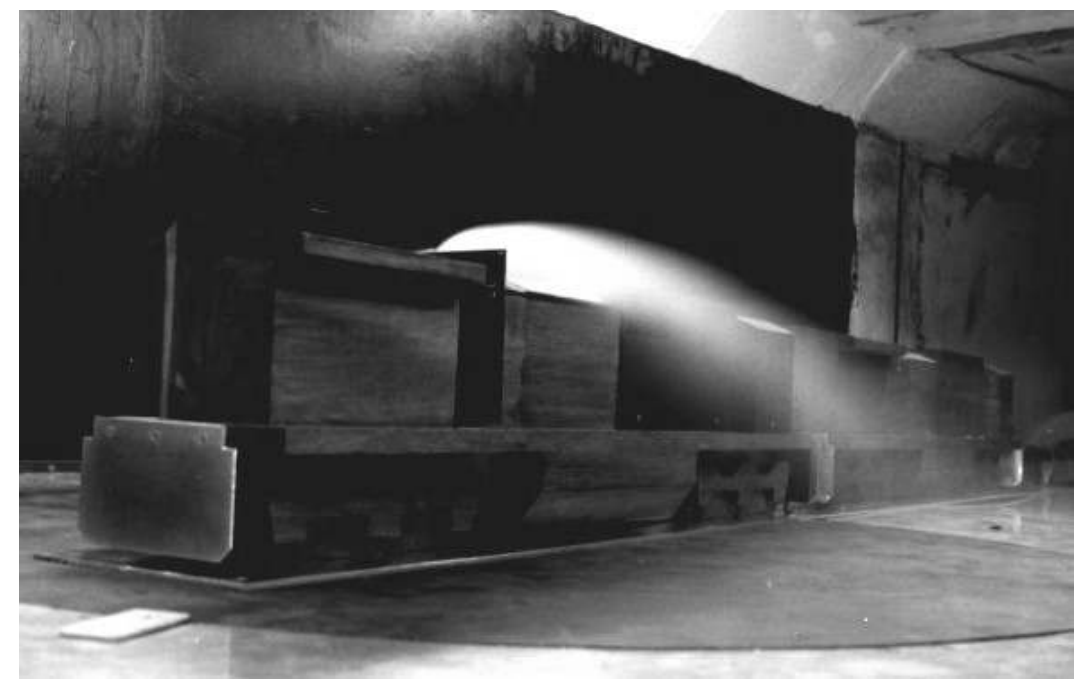

Fig. 15. Diesel Exhaust Plume Behavior: $1 / 15$-Scale Wind Tunnel Test, Yaw Angle $=10^{\circ}$, Long Hood Forward, Baseline Exhaust System

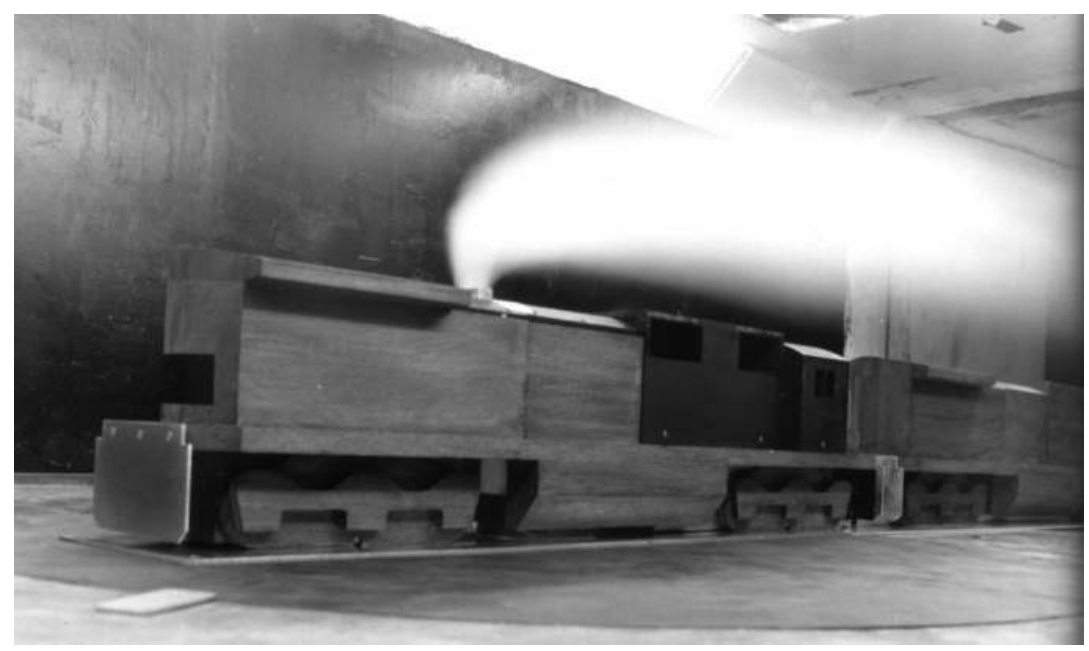

Fig. 16. Diesel Exhaust Plume Behavior, $1 / 15-$ Scale Wind Tunnel Test, Yaw Angle $=10^{\circ}$, Long Hood Forward, with Auxiliary Blower in Operation. 


\section{Approach}

To quantify the concentration of exhaust at the locomotive operator's cab window, a significant research and simulation effort was required. The approach to performing this study is outlined below and shown schematically in Figure 17.

Specific tasks included a) identification of typical switchyard and line-haul locomotives. Various references were employed, including the latest edition of The Car and Locomotive Cyclopedia of American Practices, locomotive manufacturer specifications, inventories of locomotives in various railroad fleets, and interviews with industry experts [74], b) assessment of U.S. track surveys and meteorological data, c) an evaluation of typical crosswind conditions (wind yaw angles) experienced within switchyards and line-haul operations, d) identification of typical locomotive throttle (notch) positions and train speeds for both switchyard and line-haul operations (these were used to calculate typical exhaust flow rates), e) diesel exhaust characteristics (flow rates, composition, and temperature) were obtained for a variety of locomotives, and f) other field test and wind tunnel test data relating to locomotive exhaust plume behavior were reviewed including field tests, wind tunnel tests, and CFD simulations. Concentrations of exhaust gas components and particulate matter at the leeward side windows of locomotives operating in both switchyard and line-haul conditions were identified for a range of operating conditions, based on the concentrations defined by the numerical models and the exhaust composition information obtained from the literature.

Full details of the exhaust concentration studies can be found in Paul and Linfield [75, 76]. A study of weather conditions [77] along a large number of railroad routes indicates that cross wind conditions occur during a majority of the time. Locomotives operating in cross wind conditions exhibit two distinct flow regions: 1) windward side of the vehicle, and 2) leeward side of the vehicle. Air flow patterns on the leeward side are characterized by large vortex formations and strong recirculating conditions. This recirculating, leeward-side wake acts to entrain gases emitted at the diesel engine exhaust stack.

To define effects of cross winds, both the track orientation and ambient wind patterns must be evaluated. During earlier studies [75, 76], specific track orientations were obtained from survey data and combined with historical wind records to determine the relative angle and speed of the air approaching the train. Analyses of train routes, train speeds, and ambient wind conditions indicate yaw angles vary from $5^{\circ}$ to $69^{\circ}$. Lower yaw angles apply to higher train speeds and lower wind speeds. Higher yaw angles correspond to lower train speeds and higher wind speeds.

A review of existing locomotive exhaust test data indicated flow rates are linearly proportional to engine horsepower [78]. Thus, for each throttle setting (also 


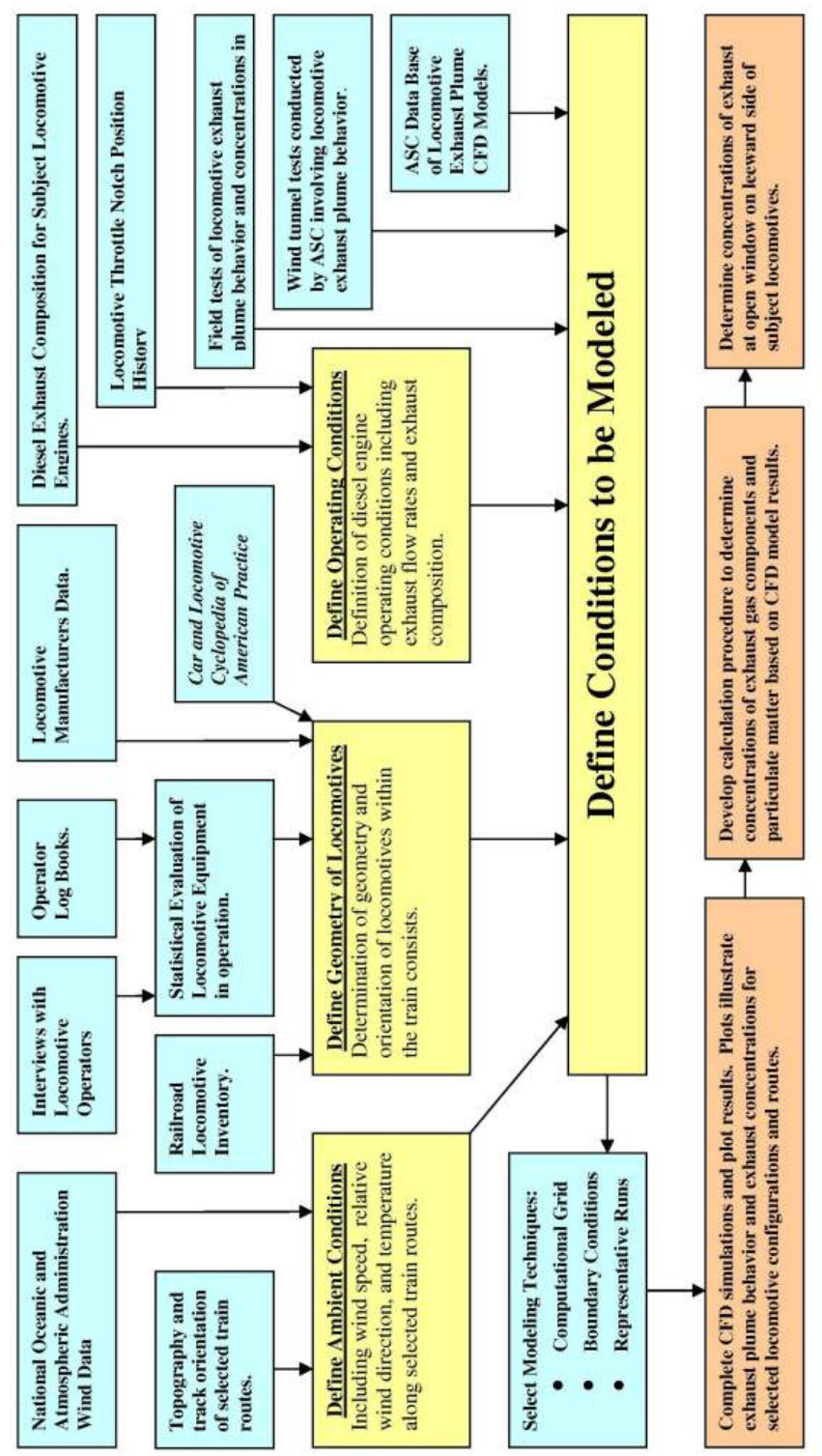

Fig. 17. Determination of Diesel Exhaust Plume Concentrations within Locomotive Cabs, Project Flow Chart. 
called "notch setting") used in the numerical simulations, the diesel exhaust flow rate can be scaled from available test data for similar 2-cycle engines. Test data available in the literature, such as that reported by Southwest Research Institute [79], were used to calculate exhaust gas temperatures and flow rates for a variety of locomotive models and manufacturers.

Exhaust gas composition was determined based on locomotive diesel engine test data reported in the literature (Bosch Automotive Handbook [80], Southwest Research Institute [81]). Exhaust gas components included in the current and previous studies were: 1) oxides of nitrogen $\left.\left(\mathrm{NO}_{\mathrm{x}}\right), 2\right)$ carbon monoxide $\left.(\mathrm{CO}), 3\right)$ unburned hydrocarbons, 4) sulfur dioxide $\left(\mathrm{SO}_{2}\right)$, and 5) particulate matter. The exhaust composition for typical 2-cycle diesel engines is summarized in Table 8:

Table 8. Exhaust Composition for 2-Cycle Diesel Locomotive Engines

\begin{tabular}{|l|c|c|c|c|}
\hline $\begin{array}{c}\text { Exhaust } \\
\text { Component }\end{array}$ & $\begin{array}{c}\text { Low Value } \\
\text { (g/bhp-hr) }\end{array}$ & $\begin{array}{c}\text { High Value } \\
\text { (g/bhp-hr) }\end{array}$ & $\begin{array}{c}\text { Low Value } \\
\text { (kg/bhp-sec) }\end{array}$ & $\begin{array}{c}\text { High Value } \\
\text { (kg/bhp-sec) }\end{array}$ \\
\hline $\mathrm{NO}_{\mathrm{x}}$ & 10.01 & 16.11 & $2.78 \mathrm{E}-06$ & $4.48 \mathrm{E}-06$ \\
\hline $\mathrm{CO}$ & 0.37 & 3.68 & $1.03 \mathrm{E}-07$ & $1.02 \mathrm{E}-06$ \\
\hline Unburned Hydrocarbons & 0.20 & 0.45 & $5.56 \mathrm{E}-08$ & $1.25 \mathrm{E}-07$ \\
\hline $\mathrm{SO}_{2}$ & 0.69 & 1.18 & $1.92 \mathrm{E}-07$ & $3.28 \mathrm{E}-07$ \\
\hline Particulate Matter & 0.14 & 0.24 & $3.89 \mathrm{E}-08$ & $6.67 \mathrm{E}-08$ \\
\hline
\end{tabular}

$\mathrm{g} / \mathrm{bhp}-\mathrm{hr}=$ grams per brake horsepower hour

$\mathrm{kg} / \mathrm{bhp}-\mathrm{sec}=$ kilograms per brake horsepower second

The mass fraction of diesel exhaust concentrations in the vicinity of a variety of locomotives has been calculated using the VISCOUS finite volume RANS code [5]. This code employs a staggered pressure-based solver over a Cartesian grid. The grid extended four train lengths forward of the locomotive, three train lengths aft of the trailing locomotive, 10 train heights above the locomotives and 5 train widths to each side. Initial models were evaluated using a range of grid sizes from fine to coarse in order to confirm grid independence. Boundary conditions, representing ambient wind conditions, were imposed at the outer edges of the computational domain. Additional boundary conditions relating to locomotive operation (exhaust flows, dynamic brake flows, electronics cooling flows, engine cooling system, etc.) were imposed at the appropriate geometric locations within the grid structure. The local concentrations of exhaust components were determined from the numerical simulation results (exhaust concentrations) and the exhaust components for 2-cycle diesel locomotive engines

In addition to ambient conditions (wind direction, speed, temperature), locomotive geometry, and operating conditions (exhaust flow rates, exhaust temperatures, throttle positions), field tests of locomotive exhaust plume behavior and exhaust 
component concentration measurements taken within cabs of operating locomotives were included in the analysis [82, 83, 84]. The models and field tests confirmed the characteristic windward/leeward side delineation of the flow field in the vicinity of operating locomotives operating under crosswind conditions. The strong recirculation region on the leeward side of the locomotive acts to entrain the gases emitted from the diesel engine exhaust and moves these gases along the longitudinal axis of the train.

Numerical simulations of diesel exhaust plume behavior were completed for seven locomotive types and 27 configurations (train orientation, wind speed, wind direction, exhaust flow rate). Three examples have been selected and are presented in Figures 18 through 20. Each of these figures shows the calculated concentrations at various planes along the length of the train. The red colors correspond to regions having exhaust concentrations equal to the concentration at the stack outlet plane. Orange represents regions having exhaust concentrations equal to $1 / 10^{\text {th }}$ of the concentration at the stack exit. The yellow regions have concentrations equal to $1 / 100^{\text {th }}$ of the concentration at the stack exit, and so forth. The color scale is logarithmic, so the numbers represent concentration changes that vary by powers of 10 .

The exhaust plume enters the wake on the leeward side and travels along this side of the train. Concentrations of exhaust components are higher in those wakes corresponding to higher train speeds and smaller yaw angles, such as those encountered in city-to-city runs (Figures 19 and 20). Higher yaw angles, which occur at lower train speeds and higher cross wind speeds (Figure 18), tend to enlarge the wake on the leeward side of the train and reduce the exhaust concentrations compared to those encountered at higher speeds where the wake tends to remain closer to the side of the train.

The numerical simulations indicate exhaust concentrations in the lead locomotive are highest for locomotives operated with the long hood forward. For switchyard operations (low speeds), exhaust concentrations in the lead locomotive increase with increasing yaw angles. For line-haul operations (high speeds), exhaust concentrations in the lead locomotive decrease with increasing yaw angles. Higher concentrations of exhaust occur at the leeward windows of the trailing locomotive for both the switchyard and line-haul operations. 


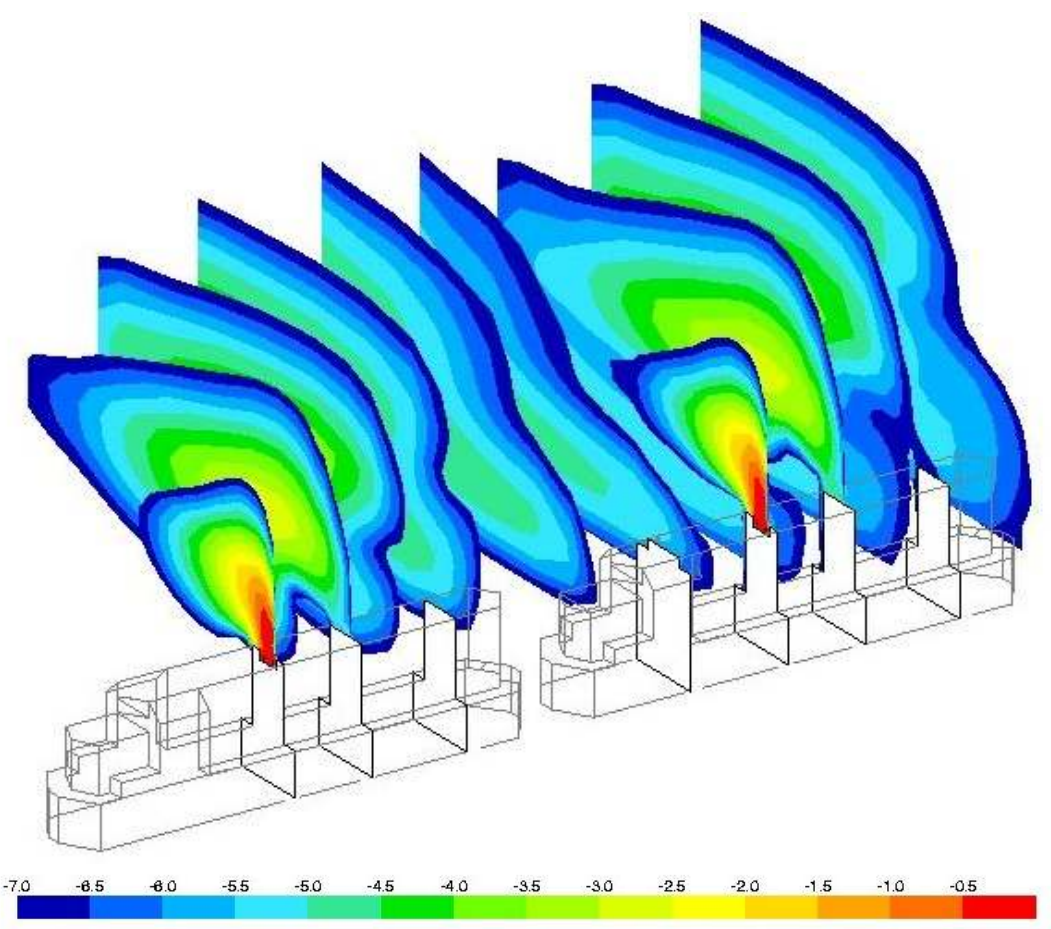

Log of Exhaust Gas Concentration

Fig. 18. Two GM EMD GP38 Locomotives, Both Oriented with Short Hood Forward, Throttle Position $=$ Notch 8 , Train Speed $=5$ miles $/$ hour, Wind Speed $=5$ miles $/$ hour $\left(45^{\circ}\right.$ Yaw $)$, Typical Low Speed (Switchyard) Operation. Train Direction: to the left; Crosswind: into the page.

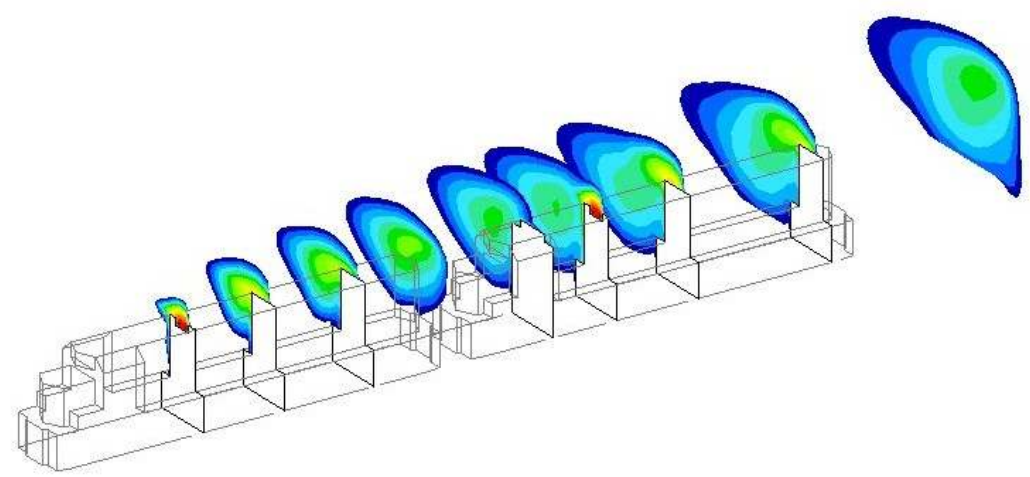

Fig. 19. Two GM EMD SD40 Locomotives, Both Oriented with Short Hood Forward, Throttle Position $=$ Notch 5, Train Speed $=45$ miles/hour, Wind Speed $=7$ miles $/$ hour $\left(8.8^{\circ}\right.$ Yaw $)$, Typical High Speed (Linehaul) Operation. Train Direction: to the left; Crosswind: into the page. 


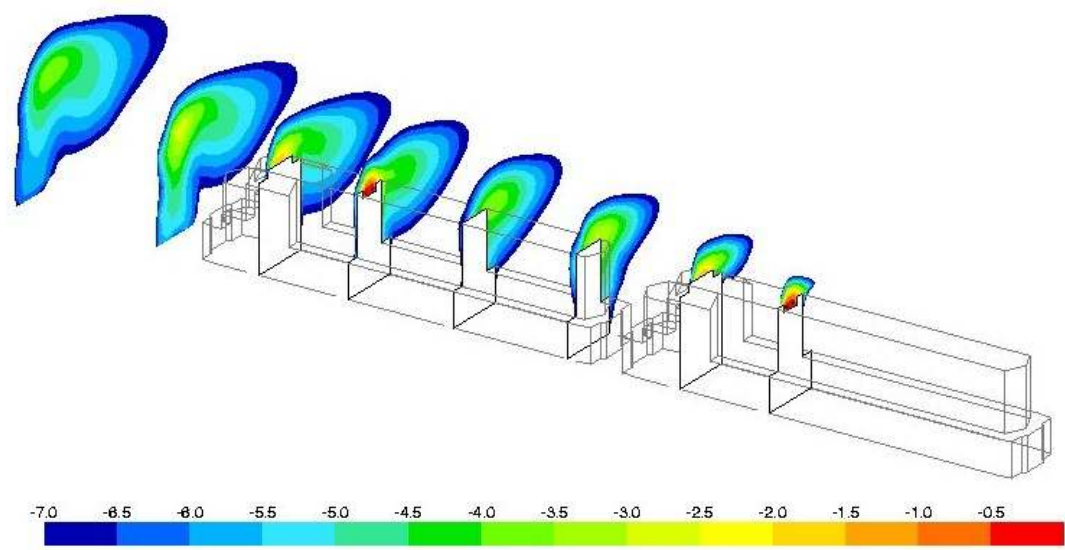

Log of Exhaust Concentration

Fig. 20. Two GM EMD SD40 Locomotives, Both Oriented with Long Hood Forward, Throttle Position $=$ Notch 5, Train Speed $=45$ miles $/$ hour, Wind Speed $=7$ miles/hour $\left(8.8^{\circ}\right.$ Yaw $)$, Typical High-Sped (Linehaul) Operation. Train Direction: to the right; Crosswind: into the page.

Maximum exhaust concentrations for the lead locomotive occur for locomotives operating in line-haul service with the long hood forward and were as high as $0.008 \%$ of the concentration at the stack exit. Concentrations of exhaust at the leeward-side window of trailing locomotives were found to be relatively higher than that of the lead locomotive for either hood orientation.

Concentrations for both the gaseous components and the particulate matter present in the exhaust plume were calculated. Exhaust concentrations were obtained from the numerical simulations and component concentrations were defined using the calculation procedures. The diesel exhaust components of Table 8 can be converted to mass fractions for comparison to the results of the numerical models as shown in Table 9. 
Table 9. Exhaust Flow Composition (Mass Fraction) for 2-Cycle, 12-Cylinder Diesel Engine as a Function of Throttle Position

\begin{tabular}{|c|c|c|c|c|c|c|}
\hline $\begin{array}{c}\text { Exhaust Gas } \\
\text { Component }\end{array}$ & $\begin{array}{c}\text { Throttle } \\
\text { Notch 5 } \\
\text { Flow Rate } \\
\text { (grams/hr) }\end{array}$ & $\begin{array}{c}\text { Throttle } \\
\text { Notch 5 } \\
\text { Flow Rate } \\
\text { (kg/sec) }\end{array}$ & $\begin{array}{c}\text { Throttle } \\
\text { Notch 5 } \\
\text { Mass } \\
\text { Fraction* }\end{array}$ & $\begin{array}{c}\text { Throttle } \\
\text { Notch 8 } \\
\text { Flow Rate } \\
\text { (grams/hr) }\end{array}$ & $\begin{array}{c}\text { Throttle } \\
\text { Notch 8 } \\
\text { Flow Rate } \\
\text { (kg/sec) }\end{array}$ & $\begin{array}{c}\text { Throttle } \\
\text { Notch 8 } \\
\text { Mass } \\
\text { Fraction* }\end{array}$ \\
\hline $\mathrm{NO}_{\mathrm{x}}$ & 25,584 & 0.0071 & 0.0027 & 47,133 & 0.0131 & 0.0038 \\
\hline $\mathrm{CO}$ & 3,895 & 0.0011 & 0.0004 & 3,034 & 0.0008 & 0.0002 \\
\hline Hydrocarbons & 595 & 0.0002 & 0.0001 & 1,375 & 0.0004 & 0.0001 \\
\hline $\mathrm{SO}_{2}$ & 1,568 & 0.0004 & 0.0002 & 3,361 & 0.0009 & 0.0003 \\
\hline Particulate & 348 & 0.0001 & 0.00004 & 697 & 0.0002 & 0.00006 \\
\hline $0_{2}$ & (reported as mass fraction): & 0.139 & (reported as mass fraction): & 0.119 \\
\hline
\end{tabular}

* Component Mass Fraction = (component flow Rate kg/sec $) /($ Total Exhaust Flow Rate kg/sec $)$

Total Exhaust Flow Rate $=3.446 \mathrm{~kg} / \mathrm{sec}($ Notch 8$)$ and $2.639 \mathrm{~kg} / \mathrm{sec}$ (Notch 5)

Gaseous Components: The molecular weight of the exhaust gas mixture at Notch Position 5 was calculated to be 28.875 [75]. Similarly, the molecular weight of the exhaust gas mixture at Notch Position 8 was determined to be 28.803. The following procedure was then applied to determine the mole fractions of each gaseous exhaust component at the leeward side windows for each of the simulated locomotives at both the leading and trailing positions.

A. For each of the selected simulations, obtain the mass fraction of exhaust present at the operator's cab leeward side window.

B. Determine the mass fraction of each exhaust component at the operator's cab window for each of the eight simulations and for both the leading and trailing locomotive (multiply component mass fraction by exhaust concentration at that location).

C. Calculate the mole fraction of the exhaust gas component.

D. Multiply the mole fraction by $1,000,000$ to obtain the concentration for each component in ppmv.

The results for the gaseous component concentrations at the leeward-side window for the leading and trailing locomotives are shown in Tables 10 and 11, respectively. 
Table 10a. Calculated Exhaust Concentrations at the Leeward-Side Window of the Leading Locomotive, $\mathrm{NO}_{x}, \mathrm{CO}$, Hydrocarbons, $\mathrm{SO}_{2}$.

\begin{tabular}{|c|c|c|c|c|c|c|}
\hline $\begin{array}{c}\text { Loco- } \\
\text { motive }\end{array}$ & $\begin{array}{c}\text { Hood } \\
\text { Forward }\end{array}$ & $\begin{array}{c}\text { Yaw } \\
\text { Angle }\end{array}$ & $\begin{array}{c}\mathbf{N O}_{\mathbf{x}} \\
(\mathbf{p p m v})\end{array}$ & $\begin{array}{c}\text { CO } \\
(\mathbf{p p m v})\end{array}$ & $\begin{array}{c}\text { HCs } \\
(\mathbf{p p m v})\end{array}$ & $\begin{array}{c}\text { SO }_{2} \\
(\mathbf{p p m v})\end{array}$ \\
\hline GP38 & Short & $45^{\circ}$ & 0.00000 & 0.00000 & 0.00000 & 0.00000 \\
\hline GP38 & Short & $21.8^{\circ}$ & 0.00000 & 0.00000 & 0.00000 & 0.00000 \\
\hline GP38 & Long & $45^{\circ}$ & 0.11646 & 0.00832 & 0.00830 & 0.00546 \\
\hline GP38 & Long & $21.8^{\circ}$ & 0.04037 & 0.00288 & 0.00288 & 0.00189 \\
\hline SD40 & Short & $49.7^{\circ}$ & 0.00000 & 0.00000 & 0.00000 & 0.00000 \\
\hline SD40 & Short & $8.84^{\circ}$ & 0.01252 & 0.00252 & 0.00126 & 0.00055 \\
\hline SD40 & Long & $49.7^{\circ}$ & 0.00621 & 0.00125 & 0.00062 & 0.00027 \\
\hline SD40 & Long & $8.84^{\circ}$ & 0.17326 & 0.03483 & 0.01738 & 0.00762 \\
\hline
\end{tabular}

Table 10b. Calculated Exhaust Concentrations at the Leeward-Side Window of the Leading Locomotive, $\mathrm{O}_{2}, \mathrm{CO}_{2}$, Aldehydes, and $\mathrm{N}_{2}$.

\begin{tabular}{|c|c|c|c|c|c|c|}
\hline $\begin{array}{c}\text { Loco- } \\
\text { motive }\end{array}$ & $\begin{array}{c}\text { Hood } \\
\text { Forward }\end{array}$ & $\begin{array}{c}\text { Yaw } \\
\text { Angle }\end{array}$ & $\begin{array}{c}\mathbf{O}_{\mathbf{2}} \\
(\mathbf{p p m v})\end{array}$ & $\begin{array}{c}\mathbf{C O}_{\mathbf{2}} \\
(\mathbf{p p m v})\end{array}$ & Aldehydes & $\begin{array}{c}\mathbf{N}_{\mathbf{2}} \\
\text { (ppmv) }\end{array}$ \\
\hline GP38 & Short & $45^{\circ}$ & 0.00000 & 0.00000 & 0.00000 & 0.00000 \\
\hline GP38 & Short & $218^{\circ}$ & 0.00000 & 0.00000 & 0.00000 & 0.00000 \\
\hline GP38 & Long & $45^{\circ}$ & 4.33325 & 1.85280 & 0.00054 & 32.5184 \\
\hline GP38 & Long & $218^{\circ}$ & 1.50206 & 0.64225 & 0.00019 & 11.27201 \\
\hline SD40 & Short & $49.7^{\circ}$ & 0.00000 & 0.00000 & 0.00000 & 0.00000 \\
\hline SD40 & Short & $8.4^{\circ}$ & 0.76606 & 0.28042 & 0.00008 & 4.80206 \\
\hline SD40 & Long & $49.7^{\circ}$ & 0.38001 & 0.13911 & 0.00004 & 2.38212 \\
\hline SD40 & Long & $8.84^{\circ}$ & 10.5982 & 3.87951 & 0.00114 & 66.43475 \\
\hline
\end{tabular}

It is noted that the concentrations in Tables 10 and 11 are for the exhaust components only. In other words, the oxygen and nitrogen components originate at the stack. Of course, oxygen and nitrogen from the surrounding air would also be present at these locations. Since the goal of the current study is to calculate the levels of exhaust components present at the operator's cab windows that originated in the engine, the concentrations of components present in the ambient air were not included. 
Table 11a. Calculated Exhaust Concentrations at the Leeward-Side Window of the Trailing Locomotive, $\mathrm{NO}_{x}, \mathrm{CO}$, Hydrocarbons, $\mathrm{SO}_{2}$.

\begin{tabular}{|c|c|c|c|c|c|c|}
\hline $\begin{array}{c}\text { Loco- } \\
\text { motive }\end{array}$ & $\begin{array}{c}\text { Hood } \\
\text { Forward }\end{array}$ & $\begin{array}{c}\text { Yaw } \\
\text { Angle }\end{array}$ & $\begin{array}{c}\text { NO } \\
(\mathbf{p p m v})\end{array}$ & $\begin{array}{c}\text { CO } \\
(\mathbf{p p m v})\end{array}$ & $\begin{array}{c}\text { HCs } \\
(\mathbf{p p m v})\end{array}$ & $\begin{array}{c}\mathbf{S O}_{\mathbf{2}} \\
\text { (ppmv) }\end{array}$ \\
\hline GP38 & Short & $45^{\circ}$ & 0.04893 & 0.00349 & 0.00349 & 0.00229 \\
\hline GP38 & Short & $21.8^{\circ}$ & 0.06834 & 0.00488 & 0.00487 & 0.00320 \\
\hline GP38 & Long & $45^{\circ}$ & 1.44415 & 0.10314 & 0.10296 & 0.06765 \\
\hline GP38 & Long & $21.8^{\circ}$ & 0.30381 & 0.02170 & 0.02166 & 0.01423 \\
\hline SD40 & Short & $49.7^{\circ}$ & 0.36723 & 0.07383 & 0.03685 & 0.01614 \\
\hline SD40 & Short & $8.84^{\circ}$ & 10.4923 & 2.10936 & 1.05280 & 0.46116 \\
\hline SD40 & Long & $49.7^{\circ}$ & 1.06756 & 0.21462 & 0.10712 & 0.04692 \\
\hline SD40 & Long & $8.84^{\circ}$ & 9.59582 & 1.92914 & 0.96285 & 0.42175 \\
\hline
\end{tabular}

Table 11b. Calculated Exhaust Concentrations at the Leeward-Side Window of the Trailing Locomotive, $\mathrm{O}_{2}, \mathrm{CO}_{2}$, Aldehydes, and $\mathrm{N}_{2}$.

\begin{tabular}{|c|c|c|c|c|c|c|}
\hline $\begin{array}{c}\text { Loco- } \\
\text { motive }\end{array}$ & $\begin{array}{c}\text { Hood } \\
\text { Forward }\end{array}$ & $\begin{array}{c}\text { Yaw } \\
\text { Angle }\end{array}$ & $\begin{array}{c}\mathbf{O}_{\mathbf{2}} \\
(\mathbf{p p m v})\end{array}$ & $\begin{array}{c}\mathbf{C O}_{\mathbf{2}} \\
(\mathbf{p p m v})\end{array}$ & $\begin{array}{c}\text { Alde- } \\
\text { hydes }\end{array}$ & $\begin{array}{c}\mathbf{N}_{\mathbf{2}} \\
\text { (ppmv) }\end{array}$ \\
\hline GP38 & Short & $45^{\circ}$ & 1.82078 & 0.77852 & 0.00023 & 13.6638 \\
\hline GP38 & Short & $21.8^{\circ}$ & 2.54299 & 1.08732 & 0.00032 & 19.0835 \\
\hline GP38 & Long & $45^{\circ}$ & 53.7351 & 22.9759 & 0.00673 & 403.248 \\
\hline GP38 & Long & $21.8^{\circ}$ & 11.3044 & 4.83351 & 0.00142 & 84.8327 \\
\hline SD40 & Short & $49.7^{\circ}$ & 22.4631 & 8.22271 & 0.00241 & 140.810 \\
\hline SD40 & Short & $8.84^{\circ}$ & 641.808 & 234.937 & 0.06886 & $4,023.18$ \\
\hline SD40 & Long & $49.7^{\circ}$ & 65.3021 & 23.9042 & 0.00701 & 409.347 \\
\hline SD40 & Long & $8.84^{\circ}$ & 586.971 & 214.864 & 0.06298 & $3,679.43$ \\
\hline
\end{tabular}

Particulate Matter: Emissions and exposure guidelines for diesel particulate matter are generally given in units of mass per unit volume, typically, milligrams per cubic meter. As was done with the gaseous components, a calculation procedure was developed to determine the concentrations of diesel particulate at the leewardside windows of the leading and trailing locomotives represented in the numerical simulations. The initial calculations involve determination of the total exhaust concentration at the locomotive window locations. The concentration of exhaust, in units of percent of total mass, at the leeward-side windows of both the leading and trailing locomotives can be taken from the computer simulations. If we multiply these concentrations by $1 \times 10^{6}$, we obtain the entries in Table 12 , which are in units of parts per million based on mass. 
Table 12. Concentrations of Exhaust at Cab Windows of Leading and Trailing Locomotives on a Mass Basis

\begin{tabular}{|c|c|c|c|c|c|}
\hline $\begin{array}{c}\text { Loco- } \\
\text { Motive }\end{array}$ & $\begin{array}{c}\text { Hood } \\
\text { Forward }\end{array}$ & $\begin{array}{c}\text { Yaw } \\
\text { Angle }\end{array}$ & $\begin{array}{c}\text { Train } \\
\text { Speed } \\
(\mathbf{m p h})\end{array}$ & $\begin{array}{c}\text { Concentration of } \\
\text { Exhaust at Cab } \\
\text { Window of Lead } \\
\text { Locomotive }\left(\mathbf{p p m}_{\text {mass }}\right)\end{array}$ & $\begin{array}{c}\text { Concentration of } \\
\text { Exhaust at Cab } \\
\text { Window of Trailing } \\
\text { Locomotive (ppm }\end{array}$ \\
\hline GP38 & Short & $4^{\circ}$ & 5 & 0.000 & 16.994 \\
\hline GP38 & Short & $21.8^{\circ}$ & 5 & 0.000 & 23.734 \\
\hline GP38 & Long & $45^{\circ}$ & 5 & 40.448 & 501.519 \\
\hline GP38 & Long & $21.8^{\circ}$ & 5 & 14.019 & 105.506 \\
\hline SD40 & Short & $49.7^{\circ}$ & 5 & 0.000 & 179.038 \\
\hline SD40 & Short & $8.84^{\circ}$ & 45 & 6.106 & $5,115.433$ \\
\hline SD40 & Long & $49.7^{\circ}$ & 5 & 3.029 & 520.481 \\
\hline SD40 & Long & $8.84^{\circ}$ & 45 & 84.471 & $4,678.365$ \\
\hline
\end{tabular}

To determine the mass flow rates of particulate, the following relationship is used:

$$
\operatorname{Mdot}_{\mathrm{p}}=\mathrm{P}_{\mathrm{s}} \cdot \mathrm{HP}
$$

where:

$$
\begin{array}{lll}
\text { Mdot }_{\mathrm{p}} & = & \text { Mass Flow Rate of Particulate }(\mathrm{kg} / \mathrm{sec}) \\
\mathrm{P}_{\mathrm{s}} & = & \text { Measured Particulate Emissions }(\mathrm{kg} / \mathrm{bhp}-\mathrm{sec}) \\
\mathrm{HP} & = & \text { Engine Power (bhp) }
\end{array}
$$

For the selected engine, throttle position Notch 5 corresponds to 1,463 horsepower

\begin{tabular}{|c|c|c|c|c|c|c|}
\hline \multirow{2}{*}{$\begin{array}{l}\text { Loco- } \\
\text { motive }\end{array}$} & \multirow{2}{*}{$\begin{array}{c}\text { Throttle } \\
\text { Notch } \\
\text { Setting } \\
\end{array}$} & \multirow{2}{*}{$\begin{array}{c}\text { Engine } \\
\text { Power } \\
\text { (bhp) }\end{array}$} & \multicolumn{2}{|c|}{ Tested Emissions } & \multicolumn{2}{|c|}{ Particulate Mass Flow } \\
\hline & & & $\begin{array}{l}\text { Low Value } \\
\text { (kg/bhp-sec) }\end{array}$ & $\begin{array}{l}\text { High Value } \\
\text { (kg/bhp-sec) }\end{array}$ & $\begin{array}{c}\text { Low Value } \\
(\mathrm{kg} / \mathrm{sec})\end{array}$ & $\begin{array}{l}\text { High Value } \\
(\mathrm{kg} / \mathrm{sec})\end{array}$ \\
\hline GP38 & 8 & 2,120 & $3.89 \times 10^{-8}$ & $6.67 \times 10^{-8}$ & $8.25 \times 10^{-5}$ & $1.41 \times 10^{-4}$ \\
\hline SD40 & 5 & 1,463 & $3.89 \times 10^{-8}$ & $6.67 \times 10^{-8}$ & $5.69 \times 10^{-5}$ & $9.76 \times 10^{-5}$ \\
\hline
\end{tabular}
and Notch Position 8 corresponds to 2,120 horsepower. Thus, the particulate flow rates at the exhaust stack for these two conditions are:

Table 13. Particulate Mass Flow Rates at Exit Plane of Diesel Engine Exhaust Stack

To calculate the particulate concentrations at the cab window locations, the following relationship was used:

Particulate Concentration $\left(\mathrm{mg} / \mathrm{m}^{3}\right)=\left[\left(\mathrm{MF}_{\mathrm{e}}\right) \times\left(\mathrm{MFR}_{\mathrm{p}} / \mathrm{MFR}_{\mathrm{e}}\right)\right] \times\left[\rho_{\mathrm{m}}\right] \times\left(10^{6} \mathrm{mg} / \mathrm{kg}\right)$

where, $\quad \mathrm{MF}_{\mathrm{e}}=$ mass fraction of exhaust at leeward window location (from simulation)

$\mathrm{MFR}_{\mathrm{p}}=$ mass flow rate of particulate at exhaust stack $(\mathrm{kg} / \mathrm{sec})$

$\mathrm{MFR}_{\mathrm{e}}=$ mass flow rate of exhaust $(\mathrm{kg} / \mathrm{sec})$

$\rho_{\mathrm{m}} \quad=$ density of air and exhaust gas mixture 
The density of the air and exhaust gas mixture can be determined from the ideal gas law:

$$
\rho_{\mathrm{m}} \quad=\left[\left(\mathrm{T}_{\mathrm{ssc}}+273^{\circ} \mathrm{C}\right) /\left(\mathrm{T}_{\mathrm{w}}+273^{\circ} \mathrm{C}\right)\right] \times\left[\rho_{\mathrm{ssc}}\right]
$$

where, $\quad \mathrm{T}_{\mathrm{ssc}}=$ Temperature $\left({ }^{\circ} \mathrm{C}\right)$ at sea level, standard conditions

$\mathrm{T}_{\mathrm{w}} \quad=$ Temperature at window location $\left({ }^{\circ} \mathrm{C}\right)$

$\rho_{\mathrm{ssc}} \quad=$ Density at sea level, standard conditions

The results of the particulate concentration analysis for both the leading and trailing locomotives and for the lower and upper value of measured particulates at the stack are presented in Tables 14 and 15.

Table 14. Particulate Concentrations at Cab Windows of Leading and Trailing Locomotives Based on Lower Value of Particulate Emissions at Stack.

\begin{tabular}{|c|c|c|c|c|c|}
\hline $\begin{array}{c}\text { Loco- } \\
\text { Motive }\end{array}$ & $\begin{array}{c}\text { Hood } \\
\text { Forward }\end{array}$ & $\begin{array}{c}\text { Yaw } \\
\text { Angle }\end{array}$ & $\begin{array}{c}\text { Train } \\
\text { Speed } \\
(\mathbf{m p h})\end{array}$ & $\begin{array}{c}\text { Concentration of } \\
\text { Particulate at Cab } \\
\text { Window of Lead } \\
\text { Locomotive }\left(\mathbf{m g} / \mathbf{m}^{3}\right)\end{array}$ & $\begin{array}{c}\text { Concentration of } \\
\text { Particulate at Cab } \\
\text { Window of Trailing } \\
\text { Locomotive }\left(\mathbf{m g} / \mathbf{m}^{3}\right)\end{array}$ \\
\hline GP38 & Short & $4^{\circ}$ & 5 & 0.0000 & 0.0005 \\
\hline GP38 & Short & $21.8^{\circ}$ & 5 & 0.0000 & 0.0007 \\
\hline GP38 & Long & $4^{\circ}$ & 5 & 0.0011 & 0.0142 \\
\hline GP38 & Long & $21.8^{\circ}$ & 5 & 0.0004 & 0.0030 \\
\hline SD40 & Short & $49.7^{\circ}$ & 5 & 0.0000 & 0.0046 \\
\hline SD40 & Short & $8.84^{\circ}$ & 45 & 0.0002 & 0.1303 \\
\hline SD40 & Long & $49.7^{\circ}$ & 5 & 0.0001 & 0.0133 \\
\hline SD40 & Long & $8.84^{\circ}$ & 45 & 0.0022 & 0.1192 \\
\hline
\end{tabular}

Table 15. Particulate Concentrations at Cab Windows of Leading and Trailing Locomotives Based on Upper Value of Particulate Emissions at Stack.

\begin{tabular}{|c|c|c|c|c|c|}
\hline $\begin{array}{c}\text { Loco- } \\
\text { Motive }\end{array}$ & $\begin{array}{c}\text { Hood } \\
\text { Forward }\end{array}$ & $\begin{array}{c}\text { Yaw } \\
\text { Angle }\end{array}$ & $\begin{array}{c}\text { Train } \\
\text { Speed } \\
(\mathbf{m p h})\end{array}$ & $\begin{array}{c}\text { Concentration of } \\
\text { Particulate at Cab } \\
\text { Window of Lead } \\
\text { Locomotive }\left(\mathbf{m g} / \mathbf{m}^{\mathbf{3}}\right)\end{array}$ & $\begin{array}{c}\text { Concentration of } \\
\text { Particulate at Cab } \\
\text { Window of Trailing } \\
\left.\text { Locomotive } \mathbf{( m g} / \mathbf{m}^{3}\right)\end{array}$ \\
\hline GP38 & Short & $45^{\circ}$ & 5 & 0.0000 & 0.0008 \\
\hline GP38 & Short & $218^{\circ}$ & 5 & 0.0000 & 0.0012 \\
\hline GP38 & Long & $45^{\circ}$ & 5 & 0.0020 & 0.0244 \\
\hline GP38 & Long & $21.8^{\circ}$ & 5 & 0.0007 & 0.0051 \\
\hline SD40 & Short & $49.7^{\circ}$ & 5 & 0.0000 & 0.0078 \\
\hline SD40 & Short & $8.8^{\circ}$ & 45 & 0.0003 & 0.2234 \\
\hline SD40 & Long & $49.7^{\circ}$ & 5 & 0.0001 & 0.0228 \\
\hline SD40 & Long & $8.84^{\circ}$ & 45 & 0.0037 & 0.2044 \\
\hline
\end{tabular}


Results and Conclusions, Section III: Diesel Exhaust Plume Behavior

Calculation procedures have been developed to determine the concentrations of diesel exhaust components, both gaseous and particle, at the leeward-side operator's cab window for both leading and trailing locomotives. Exhaust concentrations were obtained from CFD simulations and component concentrations were defined using the calculation procedures.

Calculations of the exhaust concentrations and exhaust components at the locomotive leeward-side windows showed several interesting results.

a) In switchyard and low-train-speed operations, exhaust concentrations at the trailing locomotive window are typically 10 to 800 times greater than those at the leading locomotive window when both locomotives have the same hood orientation.

b) In switchyard and low-train-speed operations, exhaust concentrations at the leeward-side window of the leading locomotive when operated with the long-hood-forward are between 3 and 30 times greater than those at the same location when the locomotive is operated with the short-hood-forward.

c) For line-haul operations, the recirculation zone on the leeward side of the locomotives is very strong and remains in closer proximity to the leeward side of the train. Exhaust concentrations at the leading locomotive cab leeward-side window with the locomotives oriented with the long-hood-forward are 14 times greater than those at the same location when the locomotives are oriented with the short hood forward. For the trailing locomotive, the exhaust concentrations at the leeward window are nearly equal for both the short-hood-forward and long-hood-forward orientations, again due to the strong vortex (recirculation zone) present in this area during high-speed operation.

d) The same trends were seen with the concentrations of particulate matter.

e) Because of the strong vortex pattern and high levels of turbulence on the leeward side of the locomotive, the diesel exhaust components are transported to the interior of the operator's cab through open windows. For high-speed line-haul operation, diesel exhaust components are present at the operator's cab window even when the locomotive is operated with the short-hood forward.

\section{Conclusions and Suggestions for Future Research}

CFD methods have been shown to be effective at evaluating the aerodynamics of rail cars and locomotives. The methods were employed to quantify the drag characteristics of external railcar features including well car side-posts and interplatform gaps. Simulation results were coupled with wind tunnel tests to develop a database of tip-over tendencies for a variety of car types. Additionally, CFD models were developed for several locomotives operating under a number of am- 
bient conditions (wind speed, wind direction). The concentration of diesel exhaust at the operator cab window was quantified. Correlations of the CFD results with previously collected wind tunnel and field data were performed for many of the simulations.

Additional research is suggested including: continued evaluation of rail car drag reduction designs using advanced CFD methods, additional wind tunnel and field tests to verify the various CFD models, and wind tunnel measurements of exhaust plume concentrations to verify simulation results.

\section{Acknowledgments}

This work was funded by the following organizations, which also approved release of the results: 1) Aerodynamic Drag Reduction: The Greenbrier Companies, 2) Wind-Induced Tip-Over: Norfolk Southern Railway Company, and 3) Diesel Exhaust Plume Behavior: Doffermyre Shields Canfield Knowles \& Devine, LLP, and Romanucci \& Blandin, LLC. Preparation of this paper was funded by Airflow Sciences Corporation.

\section{References}

[1] Anderson, D.A., Tannehill, J.C., and Pletcher, R. H., Computational Fluid Dynamics and Heat Transfer, Washington, Hemisphere Publishing Corporation, 1984.

[2] Wesseling, P., Principles of Computational Fluid Dynamics, Heidelberg, Springer-Verlag, 2000.

[3] McCallen, R., Browand, F., and Ross, J. (Editors), The Aerodynamics of Heavy Vehicles: Trucks, Buses, and Trains, New York, Springer-Verlag, 2004.

[4] Hucho, W. H. (Editor), Aerodynamics of Road Vehicles, Fourth Edition, Society of Automotive Engineer, Warrendale, Pennsylvania, 1998.

[5] Nelson, R. K., and Banka, A. L., VISCOUS Users Guide, Livonia, Michigan, Airflow Sciences Corporation, 1993.

[6] Patankar, S.V., Numerical Heat Transfer and Fluid Flow, New York, Hemisphere Publishing Corporation, 1980.

[7] FLUENT 6.3 User's Manual, Lebanon, New Hampshire, ANSYS, Inc., 2007.

[8] Launder, B. E., and Spalding, D. B., Mathematical Models of Turbulence, New York, Academic Press, 1972.

[9] Launder, B. E., and Spalding, D.B., "The Numerical Computation of Turbulent Flow", Comp. Methods Appl. Mech. Eng., vol. 3, 1974, p. 269.

[10] Ahmed, Syed R., "Some Applications of RANS Methods", Section 15.6.3.2, Computational Fluid Dynamics, Chapter 15, Aerodynamics of Road Vehicles, Hucho, W. H. (Editor), Fourth Edition, Society of Automotive Engineer, Warrendale, Pennsylvania, 1998.

[11] Ellis, H., The Pictorial Encyclopedia of Railways, New York, Hamlyn Publishing Corporation, 1968, pp. 12-30. 
[12] Hammitt, A. G., "Aerodynamic Forces on Freight Trains, Volume I - Wind Tunnel Test of Containers and Trailers on Flatcars", U. S. Department of Commerce, NTIS PB-264 304, December 1976.

[13] Joshi, P.B., "Aerodynamic Forces on Freight Trains, Volume II - Full-Scale Aerodynamic Validation Tests of Trailer-On-A-Flat-Car (Series II)", U.S. Department of Commerce, NTIS PB-281 823, March 1978.

[14] Hammitt, A.G., "Aerodynamic Forces on Freight Trains, Volume III - Correlation Report, Full Scale Trailers on Flat Cars and Comparison with Wind Tunnel Results", U.S. Department of Commerce, NTIS PB-288 137, September 1978.

[15] Hammitt, A.G., "Aerodynamic Forces on Freight Trains, Volume IV - Wind Tunnel Tests of Freight Cars and New Trailer and Container Car Designs", U.S. Department of Commerce, NTIS PB80-174 899, June 1979.

[16] Hammitt, A.G., "Aerodynamic Forces on Various Configurations of Railroad Cars for Carrying Trailers and Containers. Wind Tunnel Tests of Six Scale Model Configurations", U. S. Department of Commerce, NTIS PB80-174881, January 1979.

[17] Arnold, G. E., "Synopsis, Full-Scale Aero-Drag-Measuring Gondola Car", Workshop on the Aerodynamic Drag of Trains, Derbyshire College of Higher Education, Derby, U.K., April 7-9, 1986

[18] Gawthorp, R.G., "Aerodynamics of Trains in the Open Air", Railway Engineer International, Volume 3, No. 3, May-June 1978, pp. 7-12.

[19] Dayman, D., "Demonstration of the Coast-Down Technique for Determining Train Resistances", Final Report, Jet Propulsion Laboratory, Pasadena, California, Publication No. 8385 , October 1983.

[20] Goss, W.F.M., "Atmosphere Resistance to the Motion of Railway Trains", The Engineer, 1898 (conducted at Purdue University).

[21] Hoerner, S.F., "Efficiency of Railroad Trains", Fluid Dynamic Drag, Hoerner Fluid Dynamics, Brick Town, New Jersey, 1965, pp. 12-10 to 12-15.

[22] Tietjens, O.G., and Ripley, K.C., "Air Resistance of High-Speed Trains and Interurban Cars", Transactions ASME, Vol. 54 (APM-54-23), 1932, pp. 235-251.

[23] Davis, W.J., Jr., "The Traction Resistance of Electric Locomotives and Cars", General Electric Review, Vol. 29, October 1926, pp. 685-707.

[24] Hay, W.W., Railroad Engineering, New York, John Wiley and Sons, 1982, pp. 69-89.

[25] Engdahl, R., Gielow, R.L., and Paul, J.C., "Train Resistance - Aerodynamics, Volume I of II, Intermodal Car Aerodynamics", Association of American Railroads, 1987.

[26] Paul, J.C., Gielow, R.L., Holmes, A.E., and Hickey, P.K., "Reduction of Intermodal Car Aerodynamic Drag through Computerized Flow Simulation”, American Society of Mechanical Engineers, Paper 83-RT-4, 1983.

[27] Arad, U., The 1973-1974 Arab Oil Embargo: Facts, Figures and Analysis, Washington, D.C., Hudson Institute, 1974.

[28] Widjaja, D., Scofield, J.W., Holmes, A.E., and Gielow, R.L., "An Application of Airflow Modeling Methods to the Santa Fe 10-Pack Fuel Foiler", Livonia, Michigan, Airflow Sciences Corporation Report R-80-004, 1 October 1980.

[29] MacFadyen, A., Widjaja, D., Holmes, A.E., Paul, J.C., and Gielow, R.L., “An Aerodynamic Drag Comparison of Streamlined and Conventional Locomotives Utilizing Numerical Airflow Simulation Methods", Livonia, Michigan, Airflow Sciences Corporation Report R81-011, June 1981.

[30] Hickey, P.K., MacFadyen, A., Holmes, A.E., Paul, J.C., and Gielow, R.L., "An Aerodynamic Analysis of the Trailer Train Company 4-Runner Intermodal Car Using Numerical Flow Simulation Methods", Livonia, Michigan, Airflow Sciences Corporation Report R-82005, 7 May 1982

[31] Hickey, P.K., Gielow, R.L., Holmes, A.E., and Paul, J.C., "Aerodynamic Drag Analysis of the Lo-Pac 2000 Intermodal Car”, Livonia, Michigan, Airflow Sciences Corporation Report R-82-011, 15 September 1982. 
[32] Gielow, R.L., Holmes, A.E., and Paul, J.C., "Aerodynamic Drag Analysis of the Ortner 100-Ton Rapid Discharge Car", Livonia, Michigan, Airflow Sciences Corporation Report R82-014, 15 December 1982.

[33] Hickey, P.K., Gielow, R.L., Holmes, A.E., and Paul, J.C., "Aerodynamic Modifications to the Budd Lo-Pac 2000 Intermodal Car", Livonia, Michigan, Airflow Sciences Corporation Report R-83-001, 31 January 1983.

[34] Hickey, P.K., Holmes, A.E., Paul, J.C., and Gielow, R.L., "Aerodynamic Design Study of an Aluminum Gondola Car for Pullman Standard", Livonia, Michigan, Airflow Sciences Corporation Report R-83-005, 1 April 1983.

[35] Hickey, P.K., Gielow, R.L., and Paul, J.C., "An Aerodynamic Treatment Package for the Ortner Four Pocket Rapid Discharge Coal Car", Livonia, Michigan, Airflow Sciences Corporation Report R-83-013, 5 August 1983.

[36] Paul, J.C., Smith, T.W., Gielow, M.A., and Gielow, R.L., “ 3/10 Scale Wind Tunnel Test of Skeletonized and Well-Type Intermodal Rail Cars", Livonia, Michigan, Airflow Sciences Corporation Report R-83-019, 1 October 1983.

[37] Paul, J.C., Nelson, R.L., Groesbeck, P.D., Polihonki, D.R., Banka, A., Keeler, D., and Gielow, R.L., "3/10 Scale Hopper and Gondola Rail Car Wind Tunnel Test", Livonia, Michigan, Airflow Sciences Corporation Report R-84-019, 28 December 1984.

[38] Paul, J.C., and Gielow, R.L., "Aerodynamic Enhancements of the Trailer Train Front Runner Single Platform Rail Car", Livonia, Michigan, Airflow Sciences Corporation Report R84-009, 1 June 1984.

[39] Gielow, R.L., Keeler, D.G., Polihonki, D.R., deJager, D.E., and Paul, J.C., "16\% Scale Gondola, Locomotive, and 89 Foot Car Wind Tunnel Test”, Livonia, Michigan, Airflow Sciences Corporation Report R-85-011, 31 January 1986.

[40] Engdahl, R., Gielow, R.L., and Paul, J.C., "Train Resistance - Aerodynamics, Volume II of II, Open Top Car Applications", Association of American Railroads, 1987.

[41] Furlong, C.F., Gielow, M.A., Gielow, R.L., Paul, J.C., and Nelson, R.L., "Results of Wind Tunnel and Full-Scale Tests Conducted from 1983 t 1987 in Support of The Association of American Railroad's Train Energy Program", Livonia, Michigan, Airflow Sciences Corporation Report Number R-88-010, 30 December 1988, AAR Report R-685.

[42] Furlong, C.F., Gielow, R.L., Paul, J.C., and Nelson, R.K., "Aerodynamic Subroutine User's Guide, Train Aerodynamics Simulator", Livonia, Michigan, Airflow Sciences Corporation Report R-88-003, 15 July 1988.

[43] Polihonki, D.R., Paul, J.C., and Banka, A.L., "An Aerodynamic Optimization of the Front End Design for a Proposed Euroshuttle Train Double Deck Loader", Livonia, Michigan, Airflow Sciences Corporation Report R-90-003, 15 January 1990.

[44] Johnson, R.W., "Fuel Consumption Analysis of Various Railcars", Livonia, Michigan, Airflow Sciences Corporation Report L-94-GB1-4, 12 September 1994.

[45] Johnson, R.W., "Auto Hauler Fuel Consumption Analysis", Livonia, Michigan, Airflow Sciences Corporation Report L-98-GBC-1, 28 April 1998.

[46] Johnson, R.W., "Wind Tunnel Results of a $16 \%$-Scale Partitioned Gondola Car", Livonia, Michigan, Airflow Sciences Corporation Report L-04-ICE-1, 15 December 2004.

[47] Johnson, R.W., "CFD Analysis of Smooth-Side (Husky-Stack 53) and Side Post 53 Foot Well Cars", Livonia, Michigan, Airflow Sciences Corporation Report L-06-GB5-3, 29 November 2006

[48] Johnson, R.W., "Coal Car Aerodynamics", Livonia, Michigan, Airflow Sciences Corporation Reports L-06-BNS-1 and L-07-BNS-1, 5 December 2006 and 18 April 2007.

[49] Johnson, R.W., "Maxi-X AP1 and Maxi-X MS Fuel Consumption Results", Livonia, Michigan, Airflow Sciences Corporation Report L-94-GBI-1, 24 June 1994.

[50] Watkins, S., Saunders, J.W., and Kumar, H., "Aerodynamic Drag Reduction of Goods Trains", Journal of Wind Engineering and Industrial Aerodynamics", Vol. 40 (1992) pp. $147-178$ 
[51] Saunders, J.W., Watkins, S., and Cassar, R.J., "Vortex Optimisation of Slotted Tops and Cavities of Two Different Open Rail Wagons", Journal of Wind Engineering and Industrial Aerodynamics, Vol. 49 (1993), pp. 421-430.

[52] Johnson, R.W., "CFD Analysis of Enhanced HS 40X US Well Car", Livonia, Michigan, Airflow Sciences Corporation Report L-07-GB3-1, 27 February 2007.

[53] Matschke, G., Tielkes, T., Deeg, P., and Schulte-Werning, B., "Effects of Strong Cross Winds on High-Speed Trains - A Risk Assessment Approach“, International Association for Probabilistic Safety Assessment and Management, PSAM5 Conference, Osaka, Japan, 27 November 2000.

[54] Andersson, E., Haggstrom, J., Sima, M., and Stichel, S., "Assessment of Train-Overturning Risk Due to Strong Cross-Winds“, Proceedings of the I MECH E Part F Journal of Rail and Rapid Transit, Volume 21 B, Number 3, 1 September 2004.

[55] Sanquer, S.S., Barre, C., Dufresne de Virel, M., and Cleon L.M., "Effects of Cross Winds on High-Speed Trains: Development of a New Experimental Methodology", Journal of Wind Engineering and Industrial Aerodynamics, Vol. 92, Issues 7-8, June 2004, pp. 535-545.

[56] MacNeill, R.A., Holmes, S., and Lee, H.S., "Measurement of the Aerodynamic Pressures Produced by Passing Trains", Proceedings of the 2002 ASME/IEEE Joint Rail Conference, Washington, DC, 23-25 April 2002.

[57] Holmes, S., Toma, E., and Schroeder, M., "High-Speed Passenger and Intercity Train Aerodynamic Computer Modeling", Proceedings of ME2000, The 2000 International Mechanical Engineering Congress \& Exposition, Orlando, Florida, 5-10 November 2000.

[58] Hoppmann, U., Koenig, S., Tilkes, T., and Matschke, G., "A Short-Term Strong Wind Prediction Model for Railway Application; Design and Verification“, Journal of Wind Engineering and Industrial Aerodynamics, Vol. 90, 2002, pp. 1127-1134

[59] Polihonki, D.R., Paul, J.C., Gielow, R.L., and Nelson, R.K., "An Aerodynamic Evaluation of the Front End Design for a Bombardier Mass Transit Division Proposed Euroshuttle Train Double Deck Loader (DDL) Wagon, Livonia, Michigan, Airflow Sciences Corporation Report R-90-003, 15 January 1990.

[60] Gielow, M.A., Polihonki, D.R., Gielow, R.L., Paul, J.C., and Nelson, R.K., “A TrainSpeed-Restricting System to Achieve Safe Operations under High Wind Conditions Along Certain Union Pacific Routes", Livonia, Michigan, Airflow Sciences Corporation Report R88-006, 26 August 1988.

[61] Johnson, R.W., “Auto-Max Tip-Over Analysis”, Livonia, Michigan, Airflow Sciences Corporation Report L-98-GB1-1, 12 August 1998.

[62] Johnson, R.W. and Nelson, R.K., "Norfolk Southern Company Sandusky Bay Speed Restricting System", Livonia, Michigan, Airflow Sciences Corporation, Report R-06-NF1-1, 3 April 2006.

[63] Paul, J.C., Groesbeck, P.D., Gielow, M.A., Keeler, D.G., Banka, A.L., and Gielow, R.L., "Southern Pacific Transportation Company 3/10 Scale Double-Stack Container Car Wind Tunnel Test”, Livonia, Michigan, Airflow Sciences Corporation Report R-84-015, 4 October 1984.

[64] Peters, J. L., "How to Reduce the Cross Wind Sensitivity of Trains", The Aerodynamics of Heavy Vehicles: Trucks, Buses, and Trains, McCallen, R., Browand, F., and Ross, J. (Editors), New York, Springer-Verlag, 2004, pp. 453-467.

[65] Bhatia, R., Lopipero, P., and Smith, A.H., "Diesel Exhaust Exposure and Lung Cancer", Epidemiology, Vol. 9 (1), January 1998, pp. 84-91.

[66] Nauss, K., "Diesel Exhaust: A Critical Analysis of Emissions, Exposure, and Health Effects; Summary of a Health Effects Institute (HEI) Special Report: HEI Diesel Working Group", Cambridge, Massachusetts, DieselNet Technical Report, October 1997.

[67] Woskie, S.R., Smith, T.J., Hammond, S.K., Schenker, M.B., Garshick, E., and Speizer, F.E., "Estimation of the Diesel Exposures of Railroad Workers: I. Current Exposures", American Journal of Industrial Medicine, Vol. 13, 1988, pp. 381-394. 
[68] Woskie, S.R., Smith, T.J., Hammond, S.K., Schenker, M.B., Garshick, E., and Speizer, F.E., "Estimation of the Diesel Exhaust Exposures of Railroad Workers: II. National and Historical Perspectives", American Journal of Industrial Medicine, Vol. 13, 1988, pp. 395-404.

[69] Correspondence, Brotherhood of Locomotive Engineers and Trainsmen, Cleveland, Ohio, 1986-1989.

[70] Liukonen, L.R., Grogan, J.L., and Myers, W., "Diesel Particulate Exposure to Railroad Train Crews", American Industrial Hygiene Association Journal, Vol. 63 (5), Sep.-Oct. 2002, pp. 610-616.

[71] "Diesel Engine Exhaust", Health Hazard Advisory, Hazard Evaluation System \& Information Service, California Department of Health Services, Occupational Health Branch, November 2002.

[72] American Society of Heating, Refrigeration, and Air Conditioning Engineers (ASHRAE), 2007 ASHRAE Handbook, Chapter 44, "Building Air Intake and Exhaust Design, Atlanta Georgia, 2007.

[73] Banka, A., Gielow, M.A., Paul, J.C., and Gielow, R.L., "A Wind Tunnel Evaluation of Engine Exhaust Flow Patterns from a C39-8 Locomotive, Long Hood Forward", Livonia, Michigan, Airflow Sciences Corporation Report R-86-015, 26 September 1986.

[74] Ellsworth, K.G., (Editor), and Houser, F.N. and Whitney, D.E. (Contributing Editors), The Car and Locomotive Cyclopedia of American Practice, Fourth Edition, Simmons-Boardman Publishing Corporation, Omaha, Nebraska, 1980.

[75] Paul, J.C., Linfield, K.W., and Banka, A.L., "Determination of Diesel Exhaust Plume Concentrations within Operator Cabs of Selected Locomotives", Livonia, Michigan, Airflow Sciences Corporation Report R-04-DS1-01, 3 December 2004.

[76] Paul, J.C. and Linfield, K.W., "Assessment of Diesel Exhaust Plume Exposure Levels within Operator Cabs of Railroad Locomotives", Livonia, Michigan, Airflow Sciences Corporation Report R-06-RBL-01, 19 October 2006.

[77] National Climatic Data Center, Asheville, North Carolina, Climatic Wind Data for the United States, November 1998, for the time period 1930 through 1996. Refer to Web Site: www.ncdc.noaa.gov.

[78] Fritz, S.G., Southwest Research Institute, "Locomotive Exhaust Emissions: Past Studies, Present Work, and Future Challenges", Presentation to the Society of Automotive Engineers, TC-9 Committee Meeting, Salt Lake City, Utah, January 1998.

[79] Fritz, S.G., Southwest Research Institute, "Emissions Measurements - Locomotives", EPA Work Assignments 1-4 and 2-4, Contract No. 68-C2-0144, SwRI Report No. 5374-024, August 1995.

[80] Bauer, H., Editor in Chief, Bosch Automotive Handbook, $4^{\text {th }}$ Edition, 1996, Published by Robert Bosch GmbH, "Exhaust Emissions from Diesel Engines", pp. 530-531.

[81] Fritz, S.G., Southwest Research Institute, "Diesel Fuel Effects on Locomotive Exhaust Emissions", $23^{\text {rd }}$ CIMAC Congress, Paper No. 7A-05, May 2001.

[82] Video Tape (VHS Format) provided by General Electric Transportation Systems, GE WMM Loco Track Test on NS Smoke Ventilation”, 17 August 1989.

[83] Whitaker, L.D., "Diesel Exhaust Fume Study in GE C39-8 Cabs", Norfolk Southern Corporation, Mechanical Department, File 142.3, 22 August 1988.

[84] Beem, D.M., "Diesel Fume Monitoring, Locomotive 3532”, Norfolk Southern Corporation, File IH13, 13 September 1994. 